\title{
UMA PONTE PARA A ESPECULAC̄̃O - ou a arte da renda na montagem de uma "cidade global"1
}

\author{
Mariana Fix
}

\begin{abstract}
Este artigo analisa conflitos e articulações por trás da transformação de uma antiga área alagadiça, as várzeas do rio Pinheiros, em uma das regiões mais valorizadas de São Paulo e, atualmente, sua fachada globalizada. O texto discute, particularmente, os nexos que se constituem, nas últimas décadas, entre a financeirização global da economia e os arranjos específicos que se configuram em São Paulo; entre mecanismos supostamente avançados - como operações urbanas, Cepacs e fundos de investimento imobiliário - e formas típicas de acumulação primitiva, nas quais força, fraude, opressão e pilhagem são exibidas de modo recorrente; entre "a cidade própria" das elites e a cidade dita clandestina, que ocupa beiras de córrego, encostas de morros, margens de represas. Tomo como referência três ícones dessa paisagem urbana: uma ponte estaiada, imagem-síntese da cenografia da "nova cidade"; um gigantesco emprendimento murado, que mescla residência, comércio de luxo e escritórios; e um complexo empresarial com torres de escritório e hotel, interligados por um shopping subterrâneo.

PALAVRAS-CHAVE: globalização, financeirização, imóveis, São Paulo, cidade global.
\end{abstract}

\section{UM “CARTÃO POSTAL” EM DOIS TEMPOS}

Em 10 de maio de 2008, foi inaugurada a ponte estaiada sobre o rio Pinheiros, com desfile de carros antigos, palanque de políticos de diversos partidos e protestos de ciclistas e moradores de favelas da região. Anunciada como novo cartão-postal de São Paulo, virou capa de muitas revistas e motivo para cartazes e anúncios publicitários de todo tipo. A maior obra de infraestrutura realizada na cidade nos últimos anos tem capacidade para 8 mil carros por hora; em sua construção, consumiu 492 toneladas de cabos de aço, 58.700 metros cúbicos de concreto e 7 mil tonela-

* Arquiteta e urbanista. Doutoranda no Instituto de Economia da Unicamp. Mestre em sociologia no Departamento de Sociologia da Faculdade de Filosofia Ciências e Letras da USP. Professora do curso de Design das Faculdades Campinas (Facamp) e integrante do Laboratório de Habitação e Urbanismo da FAUUSP.

Rua do Lago, 876. Cep: 05508- 900 - Cidade Universitária - São Paulo - Brasil.mfix@uol.com.br

${ }^{1}$ Agradeço muito a Ana Carolina Maciel, Carolina Gimenez, Flávio Villaça, Ethel Leon, Higor Carvalho, José Baravelli, Otília Arantes, Pedro Fiori Arantes e ao parecerista anônimo deste periódico pelos comentários e sugestões. das de aço. ${ }^{2}$ A solução dos tabuleiros suspensos por cabos - mais complexa do que uma transposição convencional do rio e ainda pouco experimentada no Brasil - produziu a espetaculosidade almejada pela prefeitura, que pretendia fazer da obra um "chamariz" para o mercado imobiliário, mais do que uma solução para o problema viário. $\mathrm{O}$ desenho foi inspirado em modelos estrangeiros, como as conhecidas pontes do engenheiro Santiago Calatrava, embora sem a mesma elaboração formal. Os estais amarelos, suspensos no mastro em "x" (conhecido popularmente como "estilingão"), de 138 metros de altura, produzem efeito de névoa durante o dia, e são iluminados à noite com cores diferentes, conforme a ocasião. A ponte é de uso exclusivo para automóveis e faz parte do complexo viário Real Parque. A nova transposição do rio prolonga o eixo criado pela Avenida Jornalista Roberto Marinho, interligando bairros residenciais de alto padrão (como Morumbi, recordista em lan-

\footnotetext{
2 "Ponte Estaiada é inaugurada na zona sul", O Globo Online, SPTV, 10/5/2008; "Arquitetos já criticam ponte no Brooklin, Rodrigo Brancatelli, O Estado de S. Paulo, 8/9/2007.
} 
çamentos imobiliários de prédios de apartamentos, e seu vizinho, Cidade Jardim) a um dos principais polos empresariais da cidade e ao aeroporto de Congonhas. A prefeitura planeja ainda ligar a avenida à Rodovia dos Imigrantes por meio de um túnel de 4,5 km de extensão, com custo estimado em 1 bilhão de reais.

Na margem direita do rio, o empreendimento imobiliário Parque Cidade Jardim mescla funções residenciais, de consumo e negócios, em um terreno murado de 72 mil metros, ocupados por nove edifícios de apartamentos (que variam entre 235 e 2 mil metros quadrados de área privativa), um shopping center de luxo e três torres de escritório. Os apartamentos são vendidos por preços entre 1,6 e 10 milhões de reais, e o valor geral de venda é de 1,5 bilhões. ${ }^{3}$

Um lugar nobre em São Paulo, porque, além da concentração de áreas verdes, também tem a maior renda per capita do Brasil. O padrão de vida é semelhante aos mais altos do mundo. A Cidade Jardim realmente é muito especial, um lugar bonito, charmoso, perto de tudo de bom que a cidade oferece. ${ }^{4}$

O empreendimento assumiu o nome do bairro residencial situado logo atrás, e suas torres foram batizadas em homenagem às ruas do entorno, possivelmente uma estratégia para criar-ao menos no plano do marketing - um mínimo de continuidade entre o novo ideal de moradia da classe dominante e o antigo padrão de urbanização das redondezas, com desenho no estilo bairro-jardim, com casas unifamiliares implantadas em ruas sinuosas.

O projeto leva ao extremo a tipologia dos enclaves fortificados e o uso do estilo neoclássico, tão em voga em São Paulo desde os anos 1990. ${ }^{5}$ Se

Valores fornecidos pela assessoria de imprensa do empreendimento. Teriam sido bem superiores, segundo a reportagem: "Cobertura mais cara do Brasil custa $\mathrm{R} \$ 18$ mi e tem 17 vagas de carros", de Adriana Mattos, na Folha de S. Paulo, publicada em 18 maio 2006. Acesso em: 14 maio 2009.

${ }^{4}$ www.parquecidadejardim.com.br. Acesso em: 11 junho 2008. Ver, sobre o empreendimento, o texto "Cidadejardim ou anticidade", Wisnik (2009).

${ }^{5}$ Guilherme Wisnik comenta que "essas fachadas ornamentadas são, hoje, construídas muitas vezes atravé de processos racionalizados, com painéis leves produzidos em série e montados rapidamente sobre uma ossatura metálica pré-fabricada”. Desse modo, "redu- o bairro-jardim já era de uso exclusivo da classe dominante e tinha suas fronteiras delimitadas pela legislação urbanística, ${ }^{6}$ mas ainda buscava alguma qualidade no urbano, o novo empreendimento aspira a ser um "espaço total, um mundo completo, uma espécie de cidade em miniatura". ${ }^{7}$ Repete, em escala ampliada, a configuração dos condomínios "com tudo incluído", ou all included, como preferem os incorporadores, que vêm se multiplicando em São Paulo, ou do modelo já testado pela Villa Daslu, também recentemente instalada na marginal Pinheiros - exemplo máximo no Brasil do consumo de luxo -, com a diferença de que, no Parque Cidade Jardim, pode-se também morar. O sucesso do empreendimento é, possivelmente, indício da aceitação dessas gigantescas máquinas antiurbanas, que não querem fazer parte da cidade, mas se colocar como seu equivalente ou substituto - megaprojetos que integram um movimento de polarização de espaços radicalmente antagônicos nas cidades. ${ }^{8}$

É justamente como substituto de um convívio urbano perdido, ou melhor, "roubado", que o empreendimento é vendido:

Muito mais do que perspectivas arquitetônicas, ele traz perspectivas de vida que a cidade nos roubou, como caminhar depois do jantar, andar com segurança ou fazer compras a pé. São desenhos de projetos de vida. São esboços de uma cidade mais habitável, mais humana e mais saudável. ${ }^{9}$

zem em muito a área de vidro e caixilhos se comparados ao padrão de um edifício moderno. Evidentemente, não foi uma má idéia para as construtoras levantar apartamentos a custos mais baixos, e vender no mercado espaços mesquinhos sob o invólucro compensatório de uma mansarda real". ("Do calhambeque ao iPhone", em Estado crítico da arquitetura.)

${ }^{6}$ Sobre a relação entre a lei urbana e as formas concretas de produção imobiliária na cidade, ver Rolnik (1997). O bairro segue o padrão implantado pela Companhia City, como o pioneiro Jardim América (Ottoni, 1996, p.71)

Os contratos de compra e venda em loteamentos da Cia City continham diretrizes especiais, como uso exclusivamente residencial, número máximo de pavimentos, recuo frontal e de fundos, lotes mínimos, frentes mínimas, que foram, depois, oficializadas por decreto-lei municipal (Rolnik, 1997, -p.135-136).

7 Jameson, ao analisar o Bonaventure Hotel (1996).

${ }^{8}$ Cf. Mike Davis (1989, p.97). A expressão "gigantescas máquinas antiurbanas" foi utilizada por Manfredo Tafuri para descrever megaprojetos nos quais as pessoas podem trabalhar, participar da vida social e até mesmo viver sem sair deles.

${ }^{9}$ Material publicitário do empreendimento. 
Nessa cidade, contudo, não há espaço para os moradores da favela ao lado, o Jardim Panorama, assediados pela construtora para se mudarem antes da inauguração. ${ }^{10} \mathrm{~A}$ não ser, talvez, para alguns, nos pequenos cômodos dos novos edifícios, designados para as empregadas domésticas; ou para aqueles que, moradores de outras favelas mais distantes, voltam para trabalhar na construção, limpeza, manutenção ou segurança privada dos prédios. ${ }^{11}$

As tentativas de resistência incluíram um protesto organizado na noite de inauguração do stand de vendas do empreendimento, em 24 de maio de 2006. Jovens do Jardim Panorama conseguiram interromper o show de Caetano Veloso para ler o manifesto escrito pelo grupo Favela Atitude, no qual se apresentavam aos "novos vizinhos como cidadãos que sabem dos seus direitos e vão lutar para adquirir: urbanização, moradia digna e emprego". ${ }^{12}$

Os enclaves fortificados já haviam sido identificados por Teresa Caldeira, no início da década de 1990, como indícios da formação de um novo padrão de segregação urbana: "uma cidade de muros com uma população obcecada por segurança e discriminação social” (Caldeira, 2008, p.231). Embora, segundo a autora, a oposição entre centro e periferia continuasse a marcar a cidade, os processos que produziram esse padrão teriam mudado consideravelmente, e novas forças estariam gerando uma distribuição diferente das classes na cidade. São Paulo não poderia mais, pois, ser mapeada pela simples oposição centro rico versus periferia pobre. O espaço público "não se relaciona mais com o ideal moderno de universalidade”. Em vez disso, "promove a separação e a idéia de que os

${ }^{10}$ Sobre os conflitos entre o Parque Cidade Jardim e o Jardim Panorama, ver Tiaraju Pablo D'Andrea (2008). O autor pesquisou ainda uma reintegração de posse na favela Real Parque, também na região.

${ }^{11}$ As plantas do projeto preliminar mostram que um dos edifícios tem apartamentos de $300 \mathrm{~m}^{2}$, com "dormitório de empregada" sem janelas, de $4 \mathrm{~m}^{2}\left(6,3 \mathrm{~m}^{2}\right.$, com banheiro incluído), e "suíte máster" de $17 \mathrm{~m}^{2}$ (46 m², incluindo os 2 banheiros e os 2 closets). Guilherme Wisnik identifica no "neoclassicismo requentado" paulistano, a linha de continuidade, que havia sido interrompida pela arquitetura moderna, com a sociabilidade própria do sistema "casa-grande e senzala". As torres residenciais, na observação de Roger Bastide, respeitam as "leis da estrutura social do Brasil" e as inscrevem "nas suas linhas verticais" (Wisnik, 2009).

${ }^{12}$ D'Andrea (2008, p.54). grupos sociais devem viver em enclaves homogêneos, isolados daqueles percebidos como diferentes" (2008, p.212). Assim, "o novo padrão de segregação espacial serve de base a um novo tipo de esfera pública, que acentua as diferenças de classe e as estratégias de separação" (p.212). Os enclaves são representados, no livro, pelos condomínios fechados (como o pioneiro Portal do Morumbi), conjuntos de escritórios, prédios de apartamentos e shopping centers. Ainda distantes, talvez, do que viriam a ser os enclaves do novo milênio, como o empreendimento Parque Cidade Jardim, no que diz respeito a padrão estético, tipologia, ostentação de riqueza e mescla de usos. A autora interpretou, na época, a ostensiva separação social como uma reação à ampliação do processo de democratização, "para estigmatizar, controlar e excluir aqueles que acabaram de forçar seu reconhecimento como cidadãos, com plenos direitos de se envolver na construção do futuro e da paisagem da cidade".

Parece ter localizado, assim, o início de um processo que depois se aprofundou, com a enxurrada de produtos importados (inclusive na indústria da construção), que se segue à abertura econômica do governo Collor, e com o avanço da financeirização da economia, nos governos seguintes. As novas técnicas desenvolvidas acentuam, ainda, a ilusão de autossuficiência que os enclaves criam. Acompanham, ao mesmo tempo, o movimento de privatização do público, analisado por Francisco de Oliveira. A "falsa consciência da desnecessidade do público" parece se materializar no urbano, na forma de enclaves que se fazem passar por espaços autossuficientes, mesmo quando se trata justamente do contrário. ${ }^{13} \mathrm{O}$ volume de recursos aplicados nessa região, nas várias gestões municipais - é possível notar a linha de continuidade entre elas -, é

13 "A privatização do público é a falsa consciência da desnecessidade do público. Ela se objetiva pela chamada falência do Estado, pelo mecanismo da dívida pública interna, onde as formas aparentes são as de que o privado, as burguesias emprestam ao Estado: logo, o Estado, nessa aparência, somente se sustenta como uma extensão do privado. O processo real é o inverso: a riqueza pública, em forma de fundo, sustenta a reprodutibilidade do valor da riqueza, do capital privado. Esta é a forma moderna de sustentação da crise do capital, pois anteriormente, como nos mostrou a Grande Depressão de trinta, assim como todas as grandes crises anteriores, o capital simplesmente se desvalorizava” Oliveira (1999, p.68). 
evidência empírica da importância que assume o fundo público na acumulação de capital. No lugar da suposta autossuficiência, há drenagem de recursos para sustentar a construção dessas cidades dentro da cidade. "A esse processo objetivo corresponde uma subjetivação da experiência urbana burguesa que é radicalmente antipública”, encerrada, clautrofobicamente, em um "cotidiano totalmente fechado em seu próprio círculo”. ${ }^{14}$

Do outro lado do rio Pinheiros, o Centro Empresarial Nações Unidas (Cenu) domina a paisagem. Anunciado como o maior da América Latina, foi inaugurado no final da década de 1990. Seu programa também combina vários tipos de uso: inclui torres de escritório e um hotel, interligados no subterrâneo por um shopping center, que, por sua vez, dá acesso aos andares inferiores da unidade brasileira do World Trade Center. O conjunto é composto por três volumes, cujos cortes e chanfros produzem prismas; as fachadas, sem os elementos decorativos que caracterizam o Cidade Jardim, são revestidas com vidro e granito.

O Centro Empresarial Nações Unidas e o Parque Cidade Jardim representam dois estilos recorrentes, hoje, nos complexos arquitetônicos de alto padrão. Essa alternância sugere que não se trata, do ponto de vista do mercado, de opções antagônicas. Parece haver certa preferência pela sobriedade de prédios como o Cenu para os projetos de escritórios, cuja monumentalidade resulta dos próprios volumes, revestidos de materiais nobres; e por um "neoclássico" ostentatório, cujo efeito é obtido por alvenaria rebocada e pintada, que simula os monólitos de pedra, para edifícios de moradia e consumo de luxo. Contudo, prédios de escritório, como o Plaza Iguatemi, entre outros, também são concebidos no estilo neoclássico: um "resgate do renascimento italiano", na definição do seu arquiteto, que introduziu, na composição da fachada, relevos de moedas de 25 centavos. ${ }^{15}$ Um edifício "bem elitista mesmo", no dizer do presidente da construtora, que se traduz no seu funcionamento cotidiano: elevadores diferenciados para diretores,

${ }^{14}$ Ibidem, p.70-73.

15 “Moderno e luxuoso...” (2002, p.10-16). funcionários, visitantes e manobristas.

As "perspectivas arquitetônicas" que o condomínio Parque Cidade Jardim celebra são, no sentido mais estrito do termo, garantidas pelo alargamento do campo de visão propiciado pelo leito do rio Pinheiros, que permite a percepção recíproca das fachadas urbanas das duas margens do rio agora interligadas pela ponte - além da observação do conjunto à distância. A nova centralidade passa a ser vista em bloco, do ponto de vista de suas interações com outras áreas sociais e paisagens de São Paulo e de outras cidades. ${ }^{16}$ Assume, portanto, graças a uma ampliação da profundidade perspéctica, um poder de imagem superior ao de outras regiões do mesmo tipo, como a Faria Lima.

Edifícios e infraestrutura urbana, portanto, ao mesmo tempo em que configuram fisicamente o espaço, nos dão a percepção que temos da cidade (Zukin, p.23), uma paisagem de poder e dinheiro que tem por trás uma história marcada por impasses e conflitos. A ponte, imagem-síntese da cenografia da "nova cidade", impõe, sobre a realidade, a realidade da sua imagem. E encobre o imenso desejo de eliminar da paisagem urbana os que ali viviam, "marcando-os ao mesmo tempo com os signos indeléveis da diferença e da indiferença". ${ }^{17}$ Contudo, o suposto triunfo que expressa é desmentido quando as contradições, aparentemente suprimidas nas superfícies reluzentes da nova centralidade, ganham visibilidade. ${ }^{18}$

Dezembro de 1995. A avenida Água Espraiada (atual Jornalista Roberto Marinho) estava em obras, e empreendimentos imobiliários multiplicavam-se na região. Algumas favelas estavam no caminho, entre elas Jardim Edith, na avenida Luis Carlos Berrini:

... os moradores olhavam incrédulos para o outro lado da avenida: tratores empurravam o entulho

${ }^{16}$ Efeito discutido por Mike Davis, em outro contexto, no livro Cidade de quartzo, p.210.

17 “São Paulo não é mais uma cidade” Santos, 2002.

${ }^{18}$ Cf. Deutsche, R. "Homeless projection and the site of urban "revitalization" (Eviction, The MIT Press, 1996). Wodiczko projetou sobre as esculturas do novo centro empresarial imagens dos moradores que foram expulsos da região, desmanchando o discurso urbano que relaciona os edifícios à cidade apenas como um ambiente físico. 
dos barracos de alvenaria derrubados. Mais adiante, trabalhadores desmontavam barracos, escoltados por uma enorme fileira de policiais, alinhada ao córrego Água Espraiada, na beira do barranco. ${ }^{19}$

Inúmeros barracos foram reduzidos a escombros. Muitos tentaram resistir ao avanço dos tratores, mas tiveram suas estratégias desarticuladas pelo rolo compressor da parceria público-privada. $\mathrm{O}$ dinheiro recebido, atualmente conhecido como “cheque-despejo", foi suficiente, no máximo, para mudar para outra favela, na maior parte dos casos, bem distante do polo empresarial.

Janeiro de 1996. Nas margens da represa Billings, região de proteção ambiental na Zona Sul - que já abrigava milhões de pessoas -, uma antiga ocupação clandestina foi apelidada Jardim Edith 2, por conta do grande número de moradores que vieram da favela com mesmo nome, na Avenida Berrini. Com as casas alagadas, tapumes de madeira faziam o papel de ponte e as crianças passeavam com água pela cintura. Dona Maria Paraíba chegara há poucos meses: “Tava tudo de plaquinha: 'vende, vende...'. Mas era bonitinho, tudo assim enxutinho. Não era assim”.

A situação resultava não de uma enchente, mas da elevação anual do nível das águas. Maria Paraíba conta sobre o cheiro de peixe, que "não é bom para comer", fala das doenças do neto, das injeções que passou a tomar no posto de saúde, da lama fétida, do lixo com o qual não estava acostumada.

Eu saí em novembro. O povo falava: 'Ah, que vergonha, o luxo encostado no lixo... ${ }^{20}$ mas era mesmo, isso aí eu não vou tirar a razão de ninguém não. Ali estava precisando tirar mesmo [...]. Está bonito. Se você passa lá você vai ver que coisa mais linda está lá, limpinho”.

No lugar da antiga favela, nesse dia, havia apenas a estação de bombeamento de águas e um canteiro de flores. O terreno, ainda livre, ocasionalmente utilizado por um circo, agora é parcial-

${ }^{19}$ Fix (2001, p.144).

${ }^{20}$ Entrevista concedida à autora, em 1996. Dona Maria refere-se à expressão utilizada em reportagem da revista Veja, "Na mira do trator. Empresários fazem vaquinha para remover favela”, publicada em 5/7/1995. mente ocupado pelas alças de acesso à ponte estaiada Octavio Frias.

A ponte é a materialidade e, ao mesmo tempo, expressão simbólica da realidade urbana que se aprofundou e consolidou nesse período, cindida entre uma 'nova cidade' para poucos - que concentra investimentos públicos e privados, cresce em metros quadrados construídos, mas perde população - e uma imensa periferia, com índices explosivos de crescimento populacional. A imagem de uma cidade de contrastes, no entanto, comum nas representações de São Paulo, não é exata. Perdem-se de vista as conexões entre essas duas realidades, para além do usual registro da existência de dois polos: de um lado, a paisagem de poder e dinheiro dos centros empresariais e residenciais de luxo; de outro, a cidade dita clandestina ou ilegal, que ocupa beiras de córrego, encostas de morros, margens de represas.

Neste artigo, procuro descrever alguns dos conflitos e articulações que estão por trás da produção de ícones como a Ponte Estaiada, o Parque Cidade Jardim e o Centro Empresarial Nações Unidas, e do skyline do qual fazem parte. ${ }^{21}$ Uma paisagem que não é mera testemunha dos poderes de transformação da expansão capitalista, mas tem lógica própria e formas específicas de contradição. ${ }^{22}$ Analiso transformações espacialmente restritas, porque confinadas ao que é estratégico: uma parcela da cidade que se projeta como uma nova

${ }^{21}$ Para isso utilizei, além de pesquisa realizada especificamente para a redação deste artigo, resultados de algumas outras investigações, como as que deram origem aos livros Parceiros da exclusão, 2001 e São Paulo Cidade Global, 2007; o texto "A 'fórmula mágica' da parceria público-privada: Operações Urbanas em São Paulo”; e ao relatório "City Report, Slums and Poverty: São Paulo", 2003; além de outras investigações inéditas, como um estudo sobre a Operação Urbana Faria Lima (realizado no âmbito da pesquisa comparativa "Grandes projetos urbanos: o que aprender com a experiência brasileira”, no ETTERN). Esses trabalhos incluíram a realização de levantamento de campo e entrevistas com agentes dos setores imobiliários (das áreas de incorporação e desenvolvimento, construção, venda, arquitetura, etc.) e financeiros (gestores de fundos de pensão, funcionários de banco e empresas de crédito, etc.), agentes institucionais, funcionários das empresas locatárias, associações de moradores, funcionários públicos, moradores de classe média e das favelas, entre outros. Reitero, aqui, os agradecimentos feitos em cada um desses trabalhos.

${ }^{22}$ Cf. David Harvey (1989, p.54). 
centralidade em São Paulo. Centralidade que é, em verdade, não um fato, mas um processo social, uma imposição espacial de poder econômico e político. Discuto algumas das estratégias que definiram o destino dessa região da cidade, transformando aquela que fora, até o início do século XX, uma área alagadiça, as várzeas do rio Pinheiros, em uma das suas regiões mais valorizadas e, atualmente, sua face globalizada.

Discuto, particularmente, os nexos que se constituem entre a financeirização global e os arranjos específicos que se configuram em São Paulo; e entre mecanismos supostamente sofisticados - como operações urbanas, Certificados de Potencial Construtivo Adicional, fundos de investimento imobiliário, sistemas construtivos avançados e formas típicas de acumulação primitiva, nas quais força, fraude, opressão e pilhagem são exibidas abertamente, de modo recorrente. ${ }^{23}$ Discuto sistemas de produção dos edifícios e da cidade, que se alimentam de formas violentas de extração de renda e de mais-valia.

A nossa hipótese é de que a lógica especulativa mercantil da produção do espaço é reciclada e adaptada às novas condições. Combina-se, contudo, com a lógica atual da mundialização financeira, que impõe novos parâmetros e temporalidades de acumulação - por meio da abertura comercial, da desregulamentação financeira, do crescimento da previdência privada, das privatizações, da transformação dos edifícios em ativos financeiros ou fundos de investimento -, ao mesmo tempo em que encontra barreiras próprias à formação social brasileira, como a desigualdade social, o padrão de segregação e o modo de inserção na economia mundial. O resultado concreto é uma paisagem que expressa algumas das incongruências do Brasil atual, ao mesmo tempo em que se assemelha a outros espaços como esse no mundo, recentemente batizados por Mike Davis "Paraísos do Mal”.

${ }^{23}$ Ver, a respeito dessa combinação, designada por David Harvey “acumulação por espoliação”, O novo imperialismo.

\section{DA VÁRZEA À CIDADE GLOBAL: recapitulan- do algumas estratégias}

Os arredores do rio Pinheiros foram alvo de estratégias imobiliárias desde a incorporação de suas várzeas à cidade, por meio das obras de retificação do rio, nos anos 1930, que tornaram a empresa canadense Light \& Power detentora do monopólio de produção e distribuição de energia, proprietária de 21 milhões de metros quadrados na cidade (Seabra, 1987). A transformação de uma região pantanosa, entre o espigão da Avenida Paulista e o rio Pinheiros, na região mais valorizada da cidade - o chamado quadrante sudoeste se deu por meio de uma articulação entre capital financeiro internacional, mercado de terras, legislação urbanística e redes de infraestrutura, para a produção dos loteamentos residenciais da Cia. City, empresa criada por um banqueiro belga e um arquiteto francês. "A racionalidade do capital monopolista já se manifesta nessas grandes concessionárias de serviços públicos, na incorporação de novas tecnologias importadas do exterior (iluminação, bondes elétricos) e nas grandes companhias loteadoras”, ${ }^{24}$ em um período no qual São Paulo se afirma como principal núcleo industrial do país. ${ }^{25}$

A área urbana se expande ao mesmo tempo em que os bairros já existentes são adensados, em um padrão que combina "intensificação da verticalização, expansão periférica e reestruturação da centralidade” (Feldman, 2004, p.124). Na década de 1960, a região da Avenida Paulista - antiga sede dos casarões da elite cafeeira - começa a ser apresentada como "novo centro" de São Paulo, ao mesmo tempo em que o centro da cidade propriamente dito passa a ser considerado "decadente" pelas elites, na medida em que crescem o comér-

${ }^{24}$ Adriano Botelho, (2007, p.139).

${ }^{25}$ São Paulo era um pequeno centro de comércio até o final do século XIX. Impulsionado inicialmente pelo café, e depois pela industrialização, passou de burgo a metrópole em apenas algumas décadas, tornando-se a maior cidade e o principal centro financeiro do país. A respeito da gama de atividades econômicas que São Paulo abrigou no período - que vão além dos rótulos de "cidade do café" e "metrópole industrial” -, ver o artigo de Flávio Saes, "São Paulo republicana: vida econômica". 
cio e os serviços orientados para as camadas populares. ${ }^{26}$ Diferentemente do centro antigo, compacto e diversificado, o dito "novo" centro era "atomizado, fragmentado, expandido e constituído por uma nuvem de áreas especializadas, misturado com vários tipos de áreas residenciais." (Villaça, 1998, p.265). A Paulista era especializada em cinemas, escritórios e sedes de bancos - e abrigará a sede da Federação das Indústrias do Estado de São Paulo. Tratava-se da formação do chamado "centro expandido", disperso e com delimitação controvertida e complexa (1998, p.265-266).

No final da década de 1970, o capital imobiliário avança no sentido sudoeste, na direção da Avenida Faria Lima e, posteriormente, das avenidas Luis Carlos Berrini e da marginal Pinheiros. As três avenidas fazem parte de um grande conjunto de vias abertas no regime militar, que privilegiou esse quadrante da cidade, na mesma época em que o automóvel tornava-se onipresente (Villaça, 2004, p.150). O quadrante sudoeste passará a concentrar as novas moradias, empregos, comércio e serviços da classe dominante (2004, p.151). Em pouco tempo, com apenas parte do projeto executado, a Faria Lima passou a ser considerada uma espécie de sucessora da Avenida Paulista, até então identificada como endereço de maior prestígio na metrópole. Em 1966, inaugurava-se o Shopping Iguatemi, o primeiro a se instalar no país.

Na marginal Pinheiros, mais ao sul, uma empresa multinacional de origem argentina foi responsável por um dos principais empreendimentos, o Centro Empresarial São Paulo, cujo objetivo era reunir os escritórios da empresa, dispersos no centro histórico da cidade. Disso resultou a criação de um dos maiores centros desse tipo na América Latina, levantado por quatro mil operários, que abrigaria também empresas que não pertenciam ao grupo, como a Rodhia, a Gessy Lever, a Mercedes-Benz e a Alcoa.

Os preços relativamente mais baixos dos terrenos da região da Avenida Berrini foram utilizados para apresentar a área também como alter-

${ }^{26}$ Villaça (1998, p.265). nativa em relação à Avenida Paulista. Na mesma época, um único agente produziu, em uma mesma avenida, 50 edifícios, o que motivou um pesquisador a caracterizar a estratégia como de perfil monopolista (Fujimoto, 1994). Por meio de uma operação agressiva de compra de terras - para adquiri-las a baixo custo -, o bairro começou a ser convertido em frentes de negócios. A população, na maioria de média ou baixa renda, “... não tinha idéia do valor de suas propriedades com as benfeitorias que seriam realizadas no local", segundo um dos empresários (1994, p.55). Além disso, a construção dos edifícios em pontos estratégicos da avenida evitava que os adquirentes de andares ou de edifícios se apropriassem da valorização futura, quando outros edifícios estivessem à venda - que era então capturada pelo próprio grupo. Ao mesmo tempo, a valorização das áreas restantes funcionava como uma espécie de barreira à entrada de concorrentes.

O resultado foi assim traduzido numa manchete de jornal: "A cidade muda de rumo". ${ }^{27} \mathrm{~A}$ formulação é emblemática da tendência de se identificar "a cidade" como aquela parte onde se concentram as camadas de mais alta renda e os interesses da classe dominante. Esse mecanismo - revelado por Flávio Villaça como o modo específico de, no urbano, interesses particulares aparecerem como universais (1988, p.344, 348) - facilita a ação do Estado, que privilegia essa fração da cidade. $\mathrm{O}$ boletim de uma conhecida empresa de consultoria imobiliária, a Jones Lang LaSalle, não deixa margem a dúvidas:

A Berrini foi amplamente beneficiada pelos investimentos públicos que facilitam o acesso à região. Para a região dos novos centros comerciais na zona sul foram canalizados nos ano 1990 cerca de $85 \%$ dos investimentos públicos em sistema viário e infraestrutura urbana na cidade. São bons exemplos o túnel Ayrton Senna, o prolongamento da avenida Faria Lima e a abertura das avenidas Água Espraiada [atual Jornalista Roberto Marinho] e Hélio Pellegrino.

Nessa época, uma nova geração de empreendimentos foi construída na região, como o World ${ }^{27}$ Jornal da Tarde, 4/8/1989. 
Trade Center e o Centro Empresarial Nações Unidas (Cenu), os quais se beneficiaram da abertura da Avenida Jornalista Roberto Marinho. O Cenu, anunciado como o maior encontro empresarial da América Latina, é considerado uma espécie de Rockfeller Center em menor escala.

Projetado por um conhecido escritório de arquitetura brasileiro, o empreendimento resulta, inicialmente, da associação de uma incorporadora brasileira com a holding da família proprietária do Unibanco, um dos principais bancos do país. A primeira torre foi executada pela Hochtief, construtora alemã que já atuava no Brasil. Durante as obras, a Tishman Speyer Properties, conhecida incorporadora norte-americana, associou-se a uma construtora brasileira, a Método Engenharia, para a compra da fração ideal do terreno correspondente a uma das torres, a maior delas. No final, entretanto, o empreendimento só se viabilizou com a participação, como proprietário, do fundo de pensão dos funcionários da Caixa Econômica Federal, a Fundação dos Economiários Federais (Funcef). Os recursos do fundo - uma entidade de previdência privada - são compostos por depósitos dos próprios trabalhadores e também da empresa, no caso uma estatal. Por fim, a terceira torre, a Leste, foi integralmente custeada pelo grupo hoteleiro Hilton, que tem sede em Londres.

A Torre Norte, avaliada em 408 milhões reais, ${ }^{28}$ foi um dos primeiros casos de formação de um fundo de investimento imobiliário no Brasil, a maneira que a Tishman encontrou para vender sua parcela do imóvel, recebida como parte do pagamento, que equivalia a $16,17 \%$ do edifício. De acordo com o esquema, estruturado, no caso, pelo banco Ourinvest, o edifício seria vendido em cotas negociáveis na Bolsa de Valores. Seria um modo de atrair pequenos e médios investidores, sem precisar fragmentar o imóvel em andares ou salas, como no sistema convencional de condomínio.

Posteriormente, a Funcef, com o objetivo de cumprir uma determinação legal que estabelece o

${ }^{8}$ Relatório da instituição administradora, Banco Ourinves S/A, de 14/8/2008. Disponível em: www. bovespa.com.br/ pdf/cTorreNorteA_281008.pdf. Acesso em: 14 maio 2009. limite máximo do percentual de imóveis que os fundos podem ter na carteira, pensou em se desfazer de parte do edifício. Por isso, ingressou também no fundo, que passou a deter $100 \%$ do imóvel. $\mathrm{O}$ enquadramento acabou por se dar, entretanto, de outra maneira, e a Fundação continua, até hoje, detentora das cotas, deixando, porém, de respeitar uma instrução da Comissão de Valores Mobiliários (CVM), que limita a participação de fundos de pensão em, no máximo, 25\% de um fundo de investimento. Para não se desfazer do ativo, a Funcef propôs uma cisão no fundo, para depois reverter sua parte ao sistema anterior de propriedade, gerida de modo convencional. ${ }^{29}$

A carteira de imóveis da Funcef inclui ainda 13 shoppings centers, 4 hotéis, 3 outros fundos de investimentos imobiliários e aproximadamente 130 imóveis para renda, ${ }^{30}$ com patrimônio total de 1,96 bilhões de reais. ${ }^{31}$ Assim como outras fundações, a Funcef compõe sua carteira imobiliária principalmente com empreendimentos de alto padrão, como grandes resorts. As escolhas e as justificativas oferecidas pelos gestores indicam que a finalidade ética, social ou política de um investimento não pode estar no horizonte de decisões dos fundos ou, ao menos, acima do compromisso com a concessão de benefícios de aposentadoria e pensão a seus participantes. É o que explica o fato de os fundos fazerem frequentemente aplicações contrárias aos interesses dos trabalhadores, de modo análogo ao que ocorre no mercado de ações, no qual se veem obrigados a buscar papéis com maior capacidade de valorização, muitas vezes, hoje, aqueles pertencentes às empresas que melhor executam programas de redução do número de trabalhadores (downsizing), terceirização e flexibilização de mãode-obra. ${ }^{32}$ Além disso, a captação de recursos no mercado de valores implica mudança nos parâmetros

${ }^{29}$ Informações fornecidas pela diretoria de investimentos imobiliários da Funcef e pelo banco Ourinvest.

${ }^{30}$ www.funcef.com.br/cgi-bin/Pagesvr.dll/Get?id_doc $=1011$. Acesso em: 14 maio 2009.

${ }^{31}$ Relatório gerencial $1^{\circ}$ trimestre de 2006, Diretoria imobiliária, Funcef.

32 "Investimentos e servidão financeira: o Brasil do último quarto de século", Paulani; Pato (2005). Cf., também, Oliveira (2003). 
de produção e gestão dos imóveis: “... os atos praticados por proprietários e empreendedores passaram a ser mais controlados, e submetidos à análise de especialistas e investidores, bem como de órgãos reguladores do mercado financeiro", explica a CVM. ${ }^{33}$ Vemos, pois, como a reforma da previdência, ao empurrar os trabalhadores para o sistema privado, acaba por atar ainda mais o futuro de gerações à lógica do padrão financeirizado de acumulação de riqueza. ${ }^{34}$

O sistema acaba por aproximar o setor imobiliário do mercado de capitais, acompanhando o movimento de financeirização da economia, embora sem a mesma liquidez de outros investimentos. Há diferenças, por exemplo, no modo como o mercado define o preço no mercado secundário de cotas de fundos de investimento imobiliário e como é feita a precificação no sistema convencional de propriedade. No mercado secundário, o preço varia mais conforme o movimento da taxa de juros. $O$ fato de o investidor individual ter perfil mais conservador do que outros do mercado financeiro faz, no entanto, com que as negociações na bolsa sejam menos frequentes, uma vez que as ofertas tendem a ser mais reduzidas. Shopping centers e torres de escritório são os imóveis de maior "apelo" para esse tipo de investidor. No caso do shopping, além da perspectiva de uma rentabilidade crescente, “... o investidor se sente dono daquilo tudo, o apelo emocional conferido pelo charme é grande...", explica um gestor. No caso do edifício, a rentabilidade crescente é mais remota, mas existe a perspectiva de valorização do imóvel, ou seja, de ganho na venda, se o preço subir. Por isso, a localização passa a ser fundamental.

Antes que os 12 mil frequentadores do maior centro empresarial da América Latina chegas-

\footnotetext{
${ }^{33}$ http://www.cvm.gov.br/port/protinv/caderno6.asp. Acesso em: 14 maio 2009.

34 "Ao contrário do que ocorre no regime de repartição simples, no regime de capitalização, que caracteriza o mercado privado, não há solidariedade intergeracional. Cada um responde apenas por si e tem um retorno futuro proporcional à sua capacidade de pagamento corrente. Aos gestores desses fundos cabe garantir o rendimento financeiro necessário para honrar os compromissos previdenciários futuros" (Paulani; Pato, não publicado). A respeito da reforma da previdência, ver Rosa Maria Marques, "Teias da desinformação".
}

sem às torres do Cenu, mais de 15 mil famílias das favelas ao lado foram obrigadas a se mudar. À época, as obras do Cenu eram separadas por um muro da favela Jardim Edith, que integrava uma grande favela linear, composta por 68 núcleos implantados nas margens de um córrego, desde que as terras foram desapropriadas para a construção de um trecho do anel viário da cidade, nos anos 1970. Após mudanças nos planos do governo, muitos imóveis desapropriados foram ocupados por funcionários do próprio poder público, e as terras serviram para a construção de moradias precárias, no início usadas por migrantes que vinham trabalhar em São Paulo, muitos deles nas indústrias de Santo Amaro. "A avenida era só mato", conta uma moradora ao descrever a avenida Berrini, quando se mudou para a favela Jardim Edith. Contudo, a região passaria, pouco depois, por um rápido processo de transformação, como vimos, por meio de estratégias imobiliárias que contribuíram para elevar bastante o preço da terra. O antigo padrão de expansão da periferia da cidade se inviabilizava, e a população favelada crescia de modo acelerado, passando de 1 a $8 \%$ do total do município entre 1973 e 1987 (Cf. Marques; Saraiva, 2004; Pasternak, 1997; Maricato, 1996; Bonduki, 1998; Fix; Arantes; Tanaka, 2003, entre outros).

As favelas ao longo do córrego Espraiada adensaram-se com a vinda de pessoas que trabalhariam nas obras dos edifícios de escritório e shoppings e, depois, como auxiliares de limpeza, manobristas, etc., ou nas residências de classe média e alta, como empregados domésticos, jardineiros, pintores, motoristas, nos anos 1970 e 1980. Viver próximo ao local de trabalho tornava-se cada vez mais importante, diante do custo do sistema de transporte e do tempo gasto nos deslocamentos.

Do ponto de vista dos interesses imobiliários, contudo, a favela era um entrave à expansão. Entre dezembro de 1995 e janeiro de 1996, a maior parte dos moradores do Jardim Edith foi violentamente expulsa, retirada que representou, porém, mais do que a remoção de um obstáculo, a possibilidade de grandes ganhos. Os custos com a abertura de uma avenida e a expulsão dos moradores, 
como veremos, foram socializados, pela ação da prefeitura, e os ganhos foram capturados por agentes privados, através da valorização dos empreendimentos imobiliários.

A condição de ilegalidade em relação à posse da terra foi utilizada para justificar os métodos utilizados na expulsão dos moradores, apesar de a legislação brasileira incluir uma série de dispositivos jurídicos sobre a função social da propriedade e em defesa do direito à cidade (Fernandes; Afonsin, 2005, entre outros), como, por exemplo, o usucapião urbano, que permite a regularização fundiária de áreas particulares ocupadas por população de baixa renda para fins de moradia por, no mínimo, cinco anos, quando não há oposição à posse.

Os habitantes da favela enfrentaram pressão, violência e terror. Foram ameaçados e forçados a abandonar rapidamente suas casas, sem alternativa de moradia. ${ }^{35}$ Constituíram movimentos de resistência para reivindicar inclusão no programa habitacional da prefeitura, que prometia construir moradias no próprio local das favelas..$^{36} \mathrm{Im}$ pedidos de permanecer no local, os moradores receberam três "propostas": a) verba de $\mathrm{R} \$ 1500,00$ (cerca de 1,5 mil dólares pelo câmbio da época, ou $\mathrm{R} \$ 3600,00$ em valores atuais corrigidos pelo IPCA) para abandonar a moradia e se mudar por conta própria; b) passagem de ônibus para voltar à "terra natal"; ou c) apartamento na periferia de São Paulo, na Zona Leste, a aproximadamente 40 quilômetros de distância do local.

A verba em dinheiro era insuficiente para a compra de nova moradia, mesmo em favelas. A oferta da passagem pressupunha que os moradores fossem migrantes das regiões norte e nordeste, quando, na verdade, muitos eram nascidos em São Paulo, integrantes de segunda ou terceira geração na cidade. A precariedade da construção, o tamanho reduzido dos apartamentos, a localização em região com pouca oferta de empregos, as parcelas

${ }^{35}$ Resumo brevemente aqui acontecimentos que relato por extenso Parceiros da exclusão.

${ }^{36}$ Chamado Cingapura, revelou-se um programa de marketing eleitoral, muito mais do que habitacional. Os edifícios eram construídos em locais estratégicos, de grande visibilidade, como se fossem outdoors. mensais a serem pagas por 25 anos, a perda dos vínculos sociais estabelecidos no bairro de origem e a violência no novo bairro (com a exigência de pagamento de "pedágio" pela passagem) eram alguns dos problemas apontados em relação ao conjunto habitacional proposto pela prefeitura. Muitos moradores alegavam que não foram sequer informados dessa possibilidade. Eram, ao contrário, induzidos a aceitar a oferta da verba em dinheiro.

Os que tentavam permanecer em suas casas eram desencorajados pelo tráfego constante dos tratores e dos caminhões de mudança que rondavam os barracos "feito urubus". Os moradores que, apesar das restrições, aceitaram a proposta habitacional da prefeitura foram colocados em alojamentos provisórios, que descreveram como uma espécie de "campo de concentração", onde sofriam ainda cortes de água e energia.

À época, teve boa repercussão na mídia a doação de 8 milhões de reais, por um grupo de 122 empresas, supostamente para resolver o problema dos moradores das favelas. O valor, contudo, era suficiente para atender apenas $15 \%$ dos moradores desse perímetro, ou $1 \%$, se considerarmos também os que foram expulsos das outras favelas da região. Desse modo, a doação funcionou, na verdade, como um pretexto para justificar a derrubada de todas as casas da favela situadas entre a Marginal e a Berrini, e não apenas daquelas que estavam no caminho da nova avenida. Esse grupo contratou a Arthur Andersen, uma das maiores empresas de consultoria do mundo, para calcular os benefícios a serem auferidos por cada doador - ou seja, o quanto ganhariam com a elevação do preço dos seus imóveis em decorrência da saída da favela. Uma combinação de cálculos econômicos cuidadosos com métodos violentos e ilegais de remoção de favelas.

No final, menos de $5 \%$ dos moradores foram assistidos por programas habitacionais. A maior parte foi para outras favelas, muitas localizadas em regiões de proteção ambiental, como as reservas de água para abastecimento da cidade. Embora políticos e empresários afirmem que a favela foi eliminada, na verdade apenas se deslocou para 
outras regiões da cidade de menor interesse para o mercado imobiliário. Isso confirma a regra de que o uso ilegal da terra é tolerado desde que não interfira nos circuitos centrais de lucro imobiliário (Cf. Maricato, 1996). Se as possibilidades de sair daquela condição já eram reduzidas, os moradores expulsos dessa região são agora praticamente condenados à ilegalidade, literalmente empurrados pelo poder público, associado aos interesses privados, para outras soluções clandestinas de habitação. Muitos continuam sob a ameaça de despejo, por exemplo, por conta das obras do Rodoanel - uma grande obra viária conduzida pelo governo do Estado - e de um parque nas margens da represa Billings, obra da atual administração municipal.

\section{UMA PONTE PARA A ESPECULAÇÃO}

Com o terreno preparado por essa operação de "limpeza social", foi aprovada, na região, uma operação urbana, realizada na madrugada do dia 28 de dezembro de 2001: a Água Espraiada. O projeto de lei era antigo, formulado inicialmente na gestão Erundina (PT, 1989-1992) e modificado nas administrações seguintes, sempre mantendo, como suposta justificativa, a "resolução" do problema habitacional dos moradores dos 68 núcleos de favelas ao longo do córrego, que deveriam ser atendidos obrigatoriamente dentro do perímetro da operação. O projeto inicial continha, inclusive, desenhos de inúmeros pequenos conjuntos habitacionais na região. Em princípio, as obras de canalização do córrego e de abertura da avenida, bem como a construção das habitações de interesse social, seriam feitas com recursos arrecadados mediante a venda de benefícios aos proprietários da região, como o direito de construir mais do que o permitido por lei. Contudo, a gestão seguinte, de Paulo Maluf (PPB, 1993-1994), não enviou o projeto para a Câmara, provavelmente porque havia interesse em estimular a concentração de novos empreendimentos em outra região, na Faria Lima.

As obras, que custaram mais de 1 bilhão de reais e foram feitas com recursos orçamentários, motivaram, contra o ex-prefeito Paulo Maluf, acusações de superfaturamento, desvio de recursos, lavagem de dinheiro público e remessa ilegal. ${ }^{37}$ Curiosamente, os custos dessas obras - monetários e sociais - não costumam ser computados quando a operação urbana é avaliada, de modo a favorecer as ilusões criadas em torno do mecanismo. Algo semelhante aconteceu em outra operação, a Faria Lima, costumeiramente apresentada como um caso de sucesso por aqueles que evitam considerar nos cálculos os investimentos públicos realizados no entorno da avenida e que contribuíram para torná-la o "filé mignon" da cidade, na definição dos promotores imobiliários.

As operações urbanas são instrumentos urbanísticos apresentados, principalmente a partir da década de 1990, como solução para a renovação ou modernização de trechos da cidade, por supostamente permitirem custear os investimentos com recursos arrecadados entre seus beneficiários. $\mathrm{O}$ exame sobre como essas operações aconteceram em São Paulo indica que, embora possam ser propostas para qualquer região da cidade, só funcionam em áreas de interesse imobiliário, acentuando, desse modo, a concentração de investimentos em poucos trechos da cidade. Paradoxalmente, os mecanismos concentradores de renda foram reforçados com o Estatuto da Cidade, que institui a obrigatoriedade de que os recursos obtidos sejam aplicados exclusivamente na área da operação, criando um circuito de reinvestimento em regiões já favorecidas. ${ }^{38}$ Assim, tenham ou não sucesso financeiro, as operações são contrárias ao desenvolvimento de políticas de distribuição de renda, democratização do acesso à terra e aos fundos públicos. Ao contrário, fragmentam o fundo público e

\footnotetext{
37 Cf. "Maluf superfaturou R\$ 432,5 mi, diz CPI", Ronald Freitas e Roberto Cosso, Folha de S. Paulo, 27/8/2001" e "Pela $1^{\mathrm{a}}$ vez, STF mantém condenação a Maluf e o obriga a ressarcir Estado", Silvana de Freitas, Folha de S. Paulo, 14/8/2007.

${ }^{38}$ Cf. Brasil. Estatuto da Cidade (Lei n $\left.{ }^{0} 10.257 / 2001\right)$, artigo VII, parágrafo 10 . Na prática, as operações urbanas em São Paulo já continham essa determinação de que os recursos deveriam ser aplicados no próprio perímetro; a mudança é que, se antes isso era estabelecido em cada projeto de lei, com o Estatuto passa a ser algo obrigatório.
} 
aumentam o controle privado sobre sua destinação. ${ }^{39}$ Além disso, seu uso tem sido sempre associado a investimentos feitos diretamente com recursos orçamentários, utilizados antes da aprovação da operação (como na Água Espraiada), ou no entorno do seu perímetro, como em outra operação, a Faria Lima - de modo a acentuar fortemente a valorização imobiliária, pressuposto básico para o funcionamento do instrumento. ${ }^{40}$

Foi no contexto da crise da dívida, na década de 1980, que as "parcerias público-privadas”, privatizações e concessões de serviços públicos, passaram a ser defendidas, quase unanimemente, $\mathrm{e}$ constituíram-se em parte fundamental da política urbana dos governos que se seguiram, fossem eles de esquerda ou de direita. O processo de urbanização do país seguiu acelerado, num quadro de grande restrição fiscal e falta de recursos para investimentos. O impasse se deu concomitantemente à extinção das políticas nacionais de saneamento e habitação e à descentralização das políticas sociais. As operações urbanas não correspondem, no caso brasileiro, a um abandono da idéia de plano, tal como aconteceu em países da Europa, com sua substituição por projetos urbanos pontuais. Segundo Villaça, os planos elaborados no país nunca atenderam às finalidades para as quais foram propostos. Para ele, o zoneamento, esse sim, teria importância no destino das cidades, e, justamente por isso, suas revisões costumam ser acompanhadas de perto pelo setor imobiliário. Assim, uma hipótese para o interesse despertado pelas operações urbanas pode ser o fato de que elas reúnem, em um mesmo projeto de lei: um programa de investimentos (característico dos planos) e a definição de novas regras de uso e ocupação do solo

${ }^{39}$ Cf. Massoneto (2003) observa que: "As operações dificultam o compartilhamento da valorização decorrente dos processos de urbanização dentro da cidade, tornando impossível uma política de redistribuição. E, assim como nos demais setores regulados, o equilíbrio sistêmico é obtido mais pelo que é excluído do que pelo que integra de fato o processo, de forma que o desenho territorial da operação urbana é tanto mais atrativo aos investidores quanto menor for o efeito distributivo possível dentro do equilíbrio da operação”.

${ }^{40}$ Discuto mais extensamente o assunto em "A fórmula mágica da parceria público-privada: operações urbanas em São Paulo”. (características do zoneamento); a legitimidade social conferida por seu suposto autofinanciamento, de modo a dispensar qualquer discussão sobre o fato de serem prioritárias ou não; e o respaldo do urbanismo dito progressista, que as identifica como um mecanismo de recuperação das chamadas "mais-valias urbanas". Tudo isso, vale dizer, de modo muito mais restrito, dirigido e controlado no tempo e no espaço. Por isso, justamente, mais interessante para o circuito imobiliário, uma vez que a criação da "exclusividade" e da diferenciação são ingredientes básicos da apropriação da renda fundiária. E, por motivos diferentes, atraente para arquitetos e urbanistas, especialmente aqueles que têm como referência modelos europeus e norte-americanos de desenho urbano. ${ }^{41}$

Após a aprovação da operação, numa nova administração do Partido dos Trabalhadores, agora com Marta Suplicy (PT, 2001-2004), os Certificados de Potencial Construtivo Adicional foram regulamentados (Cepacs). Com isso, os benefícios oferecidos nas operações urbanas, que eram ainda “comprados" diretamente na prefeitura, passaram a ser comercializados na forma de Cepacs, certificados emitidos pela prefeitura e utilizados para pagamento de obras ou leiloados na Bolsa de Valores. Como qualquer título financeiro, o preço dos certificados oscila conforme o interesse do mercado, visto que é determinado em leilões e passa, depois, a ser negociado no mercado secundário. A especificidade é que isso deve ocorrer em função da expectativa dos investidores em relação às possibilidades de valorização de uma região da cidade. Nessa lógica, passa a ser desejável, portanto, que essa valorização aconteça. Na definição da Bovespa, os Cepacs são justamente “ativos de renda variável, uma vez que sua rentabilidade está associada à valorização dos espaços urbanos". ${ }^{42}$

${ }^{41}$ A respeito da crise do plano - em sua acepção modernista - e da passagem para a ideologia do projeto, do design urbano e das intervenções pontuais, e seus desdobramentos, ver Arquitetura depois dos modernos e Urbanismo em fim de linha, de Otília Arantes. Sobre a volta de uma visão de planejamento, já na sua versão dita estratégica, ver "Uma estratégia fatal: a cultura nas novas gestões urbanas”, em Cidade do pensamento único.

42 “O que são os Cepacs”, Disponível em: www.bovespa.com.br/ Mercado/CEPAC.htm. Acesso em: 03 maio 2006. 
Com isso, cria-se a possibilidade de um novo tipo de especulação imobiliária financeirizada, com os investimentos feitos segundo os parâmetros e as expectativas próprios de uma lógica de valorização de tipo financeiro. ${ }^{43}$

Outra consequência é que a prefeitura, ao emitir os Cepacs, precisa garantir as condições para que esses ativos se valorizem, ou corre o risco de criar uma espécie de moeda podre. Começa a parecer razoável, portanto, que seja mobilizada para promover essa valorização, por exemplo, por meio da concentração ainda maior de investimentos públicos. Assim, passa a ser visto como algo positivo que os recursos arrecadados só possam ser utilizados em obras específicas, com regras determinadas na ocasião da emissão dos títulos, e que o dinheiro seja separado do caixa da prefeitura. Ou seja, a concentração de investimentos, que poderia eventualmente ser vista como algo a ser combatido, em uma cidade tão desigual como São Paulo - num país com uma das piores distribuições de renda do mundo -, parece, ao contrário, desejável e necessária, como mostra o tratamento positivo que o processo de "elitização" dos espaços da operação urbana Faria Lima recebeu em prospecto da prefeitura sobre o lançamento dos Cepacs. ${ }^{44}$ Mais do que isso, os destinos de trechos da cidade - e da população - tornam-se cada vez mais atados ao sucesso da operação imobiliária em jogo. Em resposta a um morador de favela sobre a execução ou não de uma obra na Água Espraiada, o

${ }^{43}$ Embora essa possibilidade seja criada pela emissão de Cepacs, os certificados não parecem ter se constituído, ao menos até o momento, como alternativa de aplicação financeira, uma vez que não há um mercado secundário constituído que justifique a retenção de certificados para revender. Além disso, a forma como a prefeitura utilizou os Cepacs para o pagamento das obras da ponte estaiada motivaram suspeitas de que o instrumento criaria um novo mecanismo de favorecimento de empreiteiras, mais difícil de identificar do que o superfaturamento. A suspeita foi motivada pela realização de pagamento a uma empreiteira, efetuado quando o título tinha como valor de face 411 reais. Um mês depois, a Emurb (Empresa Municipal de Urbanização) promoveu um leilão com oferta reduzida de certificados, e o título acabou sendo comercializado por 1100 reais. A prefeitura teria deixado de arrecadar 70 milhões de reais, segundo denúncia apresentada pelo Vereador Donato, apresentada na Tribuna da Câmara Municipal de São Paulo em 8/5/2008.

${ }^{44}$ Prospecto de Registro (o "Prospecto") da Operação Urbana Consorciada Faria Lima, Prefeitura de São Paulo, 26 de outubro de 2004. coordenador do conselho gestor esclareceu que há uma relação entre "continuidade da obra e financiamento": "quanto mais bem-sucedida for a realização das obras, maior o interesse do setor imobiliário em adquirir Cepacs e, consequentemente, haverá maiores possibilidades de obter recursos para a finalização das obras". ${ }^{45}$

A definição das prioridades a serem atendidas com os recursos arrecadados nos leilóes dos Cepacs da Água Espraiada ficou a cargo do grupo gestor da operação: (a) complexo de pontes do Real Parque; (b) habitações de interesse social (HIS); (c) ampliação de áreas verdes; (d) elaboração dos projetos relativos ao Plano de Intervenções. As primeiras emissões de Cepacs foram realizadas para os dois primeiros itens, com os seguintes prazos e orçamentos: 18 meses e $\mathrm{R} \$ 165$ milhões para a ponte; 15 meses e R\$36,6 milhões para HIS. Apesar de o problema habitacional ter sido largamente utilizado como justificativa para a aprovação da operação, ${ }^{46}$ apenas dois dos 17 membros do grupo eram diretamente ligados aos moradores das favelas. ${ }^{47}$ A definição da ponte como prioridade número um desobrigou a prefeitura de construir as casas enquanto as obras viárias - que beneficiam largamente essas entidades - não ficassem prontas.

OcasodoParqueCidadeJardiméparadigmático. O empreendimento só pôde assumir aquele porte por conta da compra dos Cepacs. Os recursos arrecadados, no lugar de serem redistribuídos na cidade, foram, graças aos mecanismos já discuti-

${ }^{45}$ A resposta está citada tal como redigida na ata da reunião do conselho n. ${ }^{\circ} 7 / 2005$, disponível em http:// ww2.prefeitura.sp.gov.br (acesso em 13/5/2009).

${ }^{46}$ A produção de habitações de interesse social voltou a ser utilizada para dar seguimento à operação urbana em defesa contra uma ação civil pública ajuizada pelo ministério público (n. $\left.{ }^{\circ} 172 / 053.02 .002694-6\right)$, que pedia a declaração de ilegalidade da operação.

${ }^{47} \mathrm{O}$ grupo gestor é coordenado pela Empresa Municipal de Urbanização (Emurb) e composto por 8 membros da prefeitura e representantes das seguintes entidades: Movimento Defenda São Paulo; IAB - Instituto de Arquitetos do Brasil; IE - Instituto de Engenharia; APEOP - Associação Paulista dos Empreiteiros de Obras Públicas; SECOVI - Sindicato das Empresas de Compra, Venda, Locação e Administração de Imóveis Residenciais e Comerciais de São Paulo; OAB - Ordem dos Advogados do Brasil; FAU/USP - Faculdade de Arquitetura e Urbanismo; União dos Movimentos de Moradia; associação de moradores das favelas contidas no perímetro da Operação Urbana Consorciada. 
dos, reinvestidos logo ao lado, na ponte. O ciclo vicioso explicita-se no Prospecto:

... oferece-se ao mercado imobiliário a oportunidade de adquirir Direitos Urbanísticos Adicionais para atendimento de suas necessidades antes mesmo da realização das Intervenções que, em tese, gerarão uma valorização dos imóveis do perímetro urbano respectivo, e consequentemente desses próprios direitos.

Na prática, depois de mais de 1,5 bilhão de reais gastos com obras viárias, incluindo os gastos com a abertura da avenida e as desapropriações, que abriram caminho para a operação urbana, ${ }^{48}$ nenhuma moradia social foi ainda construída. ${ }^{49} \mathrm{Ao}$ contrário, a Prefeitura voltou a pressionar os moradores das favelas pela mudança imediata para um conjunto habitacional na periferia ou, novamente, com a oferta de uma pequena verba em dinheiro para que se mudassem por conta própria, apelidada “cheque-despejo", agora na administração Serra-Kassab (PSDB, 2005-2008 e DEM, 2009).

Para tentar impedir essa nova onda de expulsões, que chegou a se iniciar, os moradores precisaram organizar uma manifestação pública e entrar com recursos jurídicos, apoiados pela Defensoria Pública. Conseguiram conquistar a garantia de um pequeno conjunto habitacional de 278 unidades, no local da favela Jardim Edith. ${ }^{50} \mathrm{O}$ conjunto será, ao mesmo tempo, testemunho de uma vitória - de moradores que resistiram por desproporção em relação ao volume gasto nas obras viárias e ao número de habitações que deveriam

${ }^{48}$ Esse valor é apenas uma referência para que se tenha idéia da enorme desproporção entre os gastos. Um levantamento preciso de todas as despesas da prefeitura certamente indicará um número ainda mais alto.

${ }^{49}$ Os únicos recursos já utilizados para essa finalidade foram os 27,5 milhões destinados para desapropriação de terrenos. A prefeitura afirma ter feito a transferência de 45 milhões para a conta da SEHAB e de 4 milhões para uma conta vinculada, que ficarão reservados. No entanto, essa reserva é uma exigência do próprio prospecto de emissão dos Cepacs, para que a prefeitura seja agora autorizada a realizar novos investimentos viários.

${ }^{50}$ Novamente, a desproporção: enquanto outros investimentos da operação urbana são bastante detalhados, nas apresentações da Emurb que constam na página da prefeitura na Internet, há apenas fotos aéreas dos terrenos nos quais os conjuntos serão construídos, no caso das habitações de interesse social. Além daquele em Jardim Edith, estão previstos mais dois conjuntos com 560 unidades no total. ser construídas. O fato de receber um projeto diferenciado em relação a outros produzidos pela prefeitura motivou o apelido de Cohab "chique", em uma reportagem. ${ }^{51} \mathrm{O}$ modelo de financiamento e o valor das prestações, a falta de participação das famílias no desenvolvimento do projeto, os custos altos de manutenção, por conta da tipologia adotada, entre outros, são indícios de que o conjunto pode não ter sido pensado para os atuais moradores de Jardim Edith. A pequena oferta de unidades provavelmente terá ainda o efeito de conferir a esses apartamentos caráter de raridade, elevando seu preço no mercado. Diante do histórico de pressão exercida pela prefeitura para a saída dos moradores, a qualidade do projeto, que deveria ser a regra para habitação de interesse social, parece, nesse caso, estar a serviço do marketing político e dos interesses imobiliários.

Em síntese, a ponte é uma espécie de "coroamento" da linha de continuidade "de políticas urbanas que periferizam os pobres e abrem avenidas à atuação do Estado em favor de interesses privados", como resumiu Maria Cristina Fernandes. ${ }^{52}$ Ao mesmo tempo, grandes empreendimentos imobiliários, do tipo "casa-trabalholazer intramuros expandem-se, espremendo as favelas remanescentes no emaranhado de suas ligações clandestinas".

\section{O CURTO-CIRCUITO DA MÁQUINA PAULISTANA DE CRESCIMENTO}

Embora as logomarcas estampadas no alto das torres possam dar a impressão de que os edifícios do Cenu pertencem a empresas estrangeiras, o empreendimento resulta, como vimos, de uma articulação que envolve um conjunto variado de agentes econômicos, brasileiros e estrangeiros, e tem como um dos seus principais proprietários um fundo de pensão brasileiro.

51 "Favela em área valorizada de SP irá abrigar Cohab ‘chique,", de Evandro Spinelli, Folha de S. Paulo, 18/5/2009, Cotidiano, C3.

52 "A ponte sobre a cidade limpa", Valor Econômico, 21/9/ 2007. 
A ilusão é reforçada porque o Brasil passava, na época em as torres foram construídas, por um "salto de desnacionalização sem precedentes", com o crescimento dos fluxos de investimento estrangeiro direito (IED) e o avanço das empresas de capital estrangeiro (ECE), a partir de 1995, e pelo processo de privatizações. Um novo modelo econômico se impunha na América Latina, particularmente no Brasil, "pela estabilização monetária a qualquer custo, com desindustrialização, desnacionalização e expansão de circuitos de valorização patrimonial e financeira." (Tavares, 1997, p.77).

Nas torres do Cenu, circulam, de fato, os beneficiários dessa virada estrutural. Boa parte dos inquilinos são empresas dos setores de serviço e financeiro, e as principais áreas de atuação são telecomunicações e tecnologia da informação (HP e Microsoft, por exemplo). Outras entraram no Brasil com os leilões da privatização, como a Duke Energy, que comprou parte das usinas da Companhia Energética de São Paulo (Cesp). Muitas têm origem norte-americana, e seu ingresso no mercado brasileiro é recente, na década de 1990, ou, mais especificamente, no período entre 1997 e $1999 .{ }^{53}$

Na época, os promotores imobiliários brasileiros também receberam visitas de estrangeiros interessados em investir no mercado local. Tudo indica que não houve, porém, naquele momento, desnacionalização correspondente no setor imobiliário, do ponto de vista da propriedade das empresas e dos edifícios, que se mantiveram predominantemente nas mãos do capital local e, em boa medida, com empresas de estrutura familiar.

O ingresso de capital estrangeiro nos outros setores, contudo, atraiu algumas das principais empresas de consultoria e incorporação do mundo, que vieram ao Brasil para atender aos novos inquilinos: empresas estrangeiras que entraram recentementena economia brasileira, e empresas nacionais que mudaram de mãos, por meio de privatização ou aquisição por capital nacional ou estrangeiro. Esses promotores imobiliários vieram a reboque do movimento das multinacionais e do IED, caso da incorporadora

${ }^{53}$ Para um quadro completo das empresas locatárias na época da inauguração do Cenu, ver São Paulo Cidade Global, p. 90-91.
Hines, que se expandiu justamente em países como o Brasil e a Rússia. A companhia teria levado para países do leste europeu moradias para executivos das multinacionais no "estilo do West", com "tudo que uma família norte-americana precisa, em países onde isso não existia”, segundo seu presidente no Brasil (Fix, 2007).

As mudanças de comportamento não vieram apenas por mãos estrangeiras. Um incorporador brasileiro resume, com uma anedota, suas pretensões, contando que um concorrente dizia trazer ao Brasil os padrões norte-americanos ao "tirar uma porção de fotos" dos prédios de Miami e reproduzir aqui suas fachadas (2007). Afirma que, ao contrário, tentou reproduzir o ciclo completo de criação de um empreendimento, mesmo se, para isso, precisasse arcar com os custos do projeto estrangeiro, bem maiores do que os cobrados por arquitetos brasileiros. Em resumo, se não houve aumento expressivo da presença de capital internacional como proprietário de ativos, cresceram a influência e o controle de algumas especializações, que geraram mudanças qualitativas importantes. ${ }^{54}$

O tipo de articulação que produziu o Cenu tem semelhanças com um arranjo montado, em meados da década de 1980, para a construção do São Paulo Office Park, na Granja Julieta, que envolveu incorporadora brasileira, empresa de consultoria estrangeira e fundos de pensão nacionais (Cf. Nobre, 2000; Fix, 2007). Depois disso, passou a ser comum investidores institucionais tornarem-se proprietários de edifícios inteiros, eliminando o problema do fracionamento da propriedade, característico dos empreendimentos anteriores, que diminuía o controle sobre o investimento, criando dificuldades na gestão e desvalorizando o empreendimento, segundo depoimentos de incorporadores (Cf. Fix, 2007). Com o novo arranjo-explicam - aumentam as possibilidades de que o prédio deixe de ser tratado como um bem de raiz, para ser encarado como "um negócio". Os espaços produzidos são alugados a empresas, que passam a dispor de maior facilidade para se deslocar, o que

${ }^{54}$ Existe, atualmente, no Brasil, um movimento de compra de empresas brasileiras do mercado imobiliário por estrangeiros, o que precisa ser investigado. 
significa que elas podem mais facilmente entrar e sair da cidade, e ampliar e reduzir suas instalações.

Se, em outros tempos, sede própria significava solidez para companhias e bancos que quisessem projetar uma imagem de respeitabilidade, a facilidade de deslocamento no tempo e no espaço ganha, nesse período, maior importância. Essas vantagens, embora não fossem inteiramente novas - pois muitas empresas já eram locatárias anteriormente-, tornaram-se mais relevantes nos anos 1990, no contexto da dita terceirização, do aumento das relações informais de trabalho e da abertura e desregulamentação financeira da economia brasileira. E foram ressaltadas por promotores imobiliários interessados no fortalecimento do mercado de edifícios de escritório de alto padrão para locação.

Da perspectiva geral do sistema, isso significa que o capital "pode se tornar mais geograficamente móvel ao preço de imobilizar uma porção do capital social total no lugar", que passa a circular no meio ambiente construído (Harvey, 1999, p.395). Quando o mesmo capitalista compra a terra, incorpora, desenvolve, constrói e vende utilizando seu próprio capital, assume vários papéis. Mas, quanto mais capital coloca nesse tipo de atividade, menos aplica diretamente nos outros setores da produção. Por esse motivo, a produção e manutenção do ambiente construído frequentemente se cristalizam em um sistema especializado, no qual cada um desempenha um papel, separadamente ou em arranjos variados. Cria-se um sistema paralelo de acumulação, com regras próprias (1999).

Um sistema desse tipo está por trás da produção dessa frente de expansão do mercado imobiliário paulistano, composto por agentes econômicos que se dedicam a uma ou a várias funções: incorporação, desenvolvimento imobiliário, financiamento, gestão da obra, construção, consultoria, arquitetura, comercialização, marketing imobiliário e administração predial, entre outras. ${ }^{55}$ Nesse

${ }^{55}$ Empresas desse tipo atuam em muitas cidades. Contudo, é inicialmente em São Paulo e, em menor escala, no Rio de Janeiro, que a promoção imobiliária vai se tornar mais "profissionalizada", e a divisão social do trabalho mais acentuada. Nos últimos anos, principalmente enquanto durou boom imobiliário, várias empresas passaram a atuar também no interior do estado de São Paulo e em outras cidades do país, expandindo esse padrão de incorporação para novas fronteiras. sistema, a figura do rentista - que não é nova, pois estava já presente quando os proprietários exploravam os imóveis para obter renda futura por longo prazo - é atualizada. Proprietários que não veem os seus imóveis como ativos financeiros raramente planejam vender e comprar rapidamente sem perder valor. No entanto, quando os edifícios são construídos como ativos financeiros, o pagamento que os proprietários recebem não é uma função marginal, mas um fim em si mesmo.

Os agentes econômicos que participam da produção do espaço em cidades cuja terra atingiu certo grau de mercantilização podem ser considerados, segundo dois sociólogos norte-americanos (Logan e Molotch), verdadeiros militantes ou ativistas (activists). Existiriam, basicamente, três tipos diferentes: o acidental (um rentista que apenas marginalmente funciona como promotor imobiliário); o ativo (que antecipa mudanças de uso do solo e especula sobre o futuro de determinados lugares, buscando a renda diferencial, prevendo o futuro e se colocando no caminho do desenvolvimento); e o estrutural (que não busca apenas prever o futuro, mas também intervém para alterá-lo, modificando as condições que estruturam o mercado; sua estratégia é criar rendas diferenciais, por meio da influência na arena de decisões que trazem vantagens a uma região em relação a outra, como a realização de obras públicas e as alterações de zoneamento; visa a apropriar-se também de renda monopolista, e não apenas diferencial).

Empreendimentos como a Torre Norte combinam ganhos advindos do canteiro de obras (lucro) com aqueles decorrentes da estratégia de desenvolvimento imobiliário (renda). A qualidade dos edifícios, em si mesma, não parece ser suficiente para o tipo de ganho almejado pelos promotores imobiliários. De acordo com gestores dos fundos de pensão, edifícios de escritórios, particularmente, precisam estar localizados em bairros valorizados - ou em processo de valorização -, para que o fluxo de rendimentos obtido com o aluguel (renda) e os ganhos patrimoniais com a venda (lucro e incremento da renda) sejam obtidos segundo os parâmetros esperados pelos investidores. No caso 
dos fundos de pensão, esses parâmetros são definidos pela lógica financeira, como vimos.

No caso da Torre Norte, notamos como se obtiveram incrementos de renda por meio de melhoramentos feitos dentro e fora do imóvel, depois capturados pelo incorporador. O fato de o empreendimento ter sido construído em um vetor de expansão da cidade - que alguns anos antes teria mudado "de rumo", como vimos - indica que se trata de um promotor imobiliário ativo, na definição de Logan e Molotch. Obteve-se novo incremento de renda, posteriormente, por meio da alteração, em termos relativos, da localização desse edifício na cidade, com a expulsão da favela e a construção da avenida e da ponte. Aqui, o diferencial de renda será capturado pelos proprietários, ou seja, os donos das cotas do fundo de investimento imobiliário. A evolução do preço por metro quadrado nas avenidas Luis Carlos Berrini e Faria Lima é, por si só, um indício da apropriação de fundo público que acontece no processo - remoções e obras são poderosos mecanismos de transferência de riqueza. Assim, a associação (pool) que se formou para forçar a remoção do Jardim Edith e a construtora do empreendimento Parque Cidade Jardim, que pressionou os moradores do Jardim Panorama a se mudarem, são exemplos de ativistas de tipo estrutural. A ponte e a avenida, contudo, não são apenas meios de expandir a base de circulação do capital no meio ambiente construído. São, também, importantes campos de produção de valor e extração de mais-valia.

Em síntese, os proprietários dos imóveis recebem renda, por meio do aluguel; os incorporadores, incrementos na renda com base nos melhoramentos realizados dentro e fora do lote; os construtores, o lucro do empreendimento, por meio da extração de mais-valia nos canteiros de obra; os agentes de crédito fornecem o capital em troca dos juros; e "o Estado pode usar os impostos (presentes ou antecipados) como apoio para investimentos que o capital não pode assumir ou não assumirá, mas que expandem a base para a circulação do capital". São papéis que existem, não importa quem os preencha (Harvey, 1999, p.395). Para Harvey, o funcionamento desse sistema não pode ser entendido sem se abordarem os fatores da distribuição: renda, juros e taxas. A renda é base do preço da terra e operação para alocar capital e trabalho na terra, guiar a localização da produção, forçar consumos futuros, moldar a divisão geográfica do trabalho e a organização espacial da reprodução social.

Falta à máquina paulistana, contudo, a figura de um sistema de crédito que desempenha o papel fundamental de coordenador das funções, atuando como uma espécie de "sistema nervoso" que regula os movimentos do capital (1999, p. 272). Na interpretação de Harvey, é o sistema de crédito que traz para um marco comum as intrincadas mediações e diversos agentes econômicos, apropriando diferentes tipos de rendimentos. No Brasil, contudo, o capital portador de juros não tem a mesma liberdade de circular pelo meio ambiente construído que encontra em países como Estados Unidos e Inglaterra. Além disso, a securitização do mercado imobiliário é, aqui, incipiente, e a interconexão entre o financeiro e o imobiliário, reduzida. A securitização não funciona como uma modalidade financeira generalizada, como nos Estados Unidos, substituindo empréstimos bancários e, ao mesmo tempo, constituindo modalidade propícia aos bancos na captação dos fundos. A vinculação dos usos da terra e da organização espacial, em um processo geral de circulação de capital - que caracterizou a bolha imobiliária norte-americana, por exemplo-, não chega a se completar. A alta taxa dos juros faz com que investimentos de rentabilidade mais baixa, como os ativos imobiliários, nem sempre tenham como recorrer às instituições de financiamento, como acontece com o setor de escritórios. A proporção de empréstimos do sistema bancário brasileiro em relação ao PIB é de pouco mais de 30\% - baixa, se comparada à norte-americana, superior a $190 \%$, ou à espanhola, 146,1\%, no mesmo período. ${ }^{56}$ Já a participação do total de financiamentos imobiliários repre-

${ }^{56} \mathrm{O}$ percentual de crédito para o setor privado em relação ao PIB era de 34,8 no Brasil e 194,8 nos Estados Unidos, em 2005, segundo dados do International Financial Statistics, do FMI, publicados no relatório "World Development Indicators 2007”, do Banco Mundial. No Brasil, o percentual subiu recentemente e, em março de 2009, chegou a $42,5 \%$, segundo o Banco Central. 
senta $2 \%$ do Produto Interno Bruto (PIB) no Brasil, $12 \%$ no México e 100\% nos Estados Unidos. ${ }^{57}$

Ainda assim, há uma abertura relativa do mercado de terras operada por outras vias. No Brasil, os fundos de pensão atuam como uma espécie de substituto do crédito, com o que se tornaram figuras centrais no setor imobiliário comercial, particularmente na proliferação dos megaprojetos nos anos 1990, como o Cenu. Essa participação tem impacto no projeto arquitetônico dos edifícios e em sua localização na cidade. Os fundos de pensão tratam a terra como um ativo financeiro, de modo a ter acesso a rendimentos futuros. Não é por acaso que os alvos dos fundos são os edifícios de mais alto padrão, classificados como A, duplo A, ou triple A. A classificação dos edifícios é feita por empresas de consultoria imobiliária, que avaliam diversas características, como o tamanho da laje e o tipo do sistema de ar condicionado instalado, características que os promotores imobiliários tomam como especificações a serem seguidas no desenvolvimento do projeto. Isso acaba por funcionar como uma espécie de padronização, que age no sentido de definir com mais precisão o produto imobiliário, eliminando as características particulares que o tornariam eventualmente interessante para uma empresa específica. Assim, cresceriam as chances de locação para maior variedade de grandes empresas e, ao mesmo tempo, aumentaria a liquidez do investimento, ou seja, a capacidade de venda em curto prazo, sem perda de valor, em caso de desmobilização do ativo.

\section{MIRAGENSURBANAS}

Edifícios como o Cenu e outros da região, como o Plaza Centenário, são projetados como acréscimos supostamente singulares ao skyline. A excepcionalidadee a particularidade são cruciais para que seus proprietários se apropriem de um fluxo de rendimentos maior, ou seja, da chamada renda

57 "Estudo de viabilidade econômico-financeira CEPAC Certificados de Potencial Adicional de Construção Operação Urbana Consorciada Água Espraiada”, julho de 2008. monopolista ${ }^{58}$ Ao mesmo tempo, o desenho das fachadas, as características técnicas, os materiais empregados e a tipologia e o layout dos andares seguem, em certa medida, parâmetros predeterminados. São características exigidas pelas empresas locatárias e, consequentemente, pelos investidores, particularmente aqueles que tratam o empreendimento como um ativo financeiro, exigindo, acima de tudo, rentabilidade elevada e liquidez. Em síntese, são prédioslogomarca, que ditam um novo estilo, ao mesmo tempo em que procuram responder mais adequadamente aos propósitos dos investimentos.

Desse modo, embora utilize todos os meios para se diferenciar, nenhum produto pode ser tão excepcional ou especial a ponto de ficar totalmente à margem do cálculo monetário, contradição apontada pelo geógrafo David Harvey (2005, p.32-34). Quanto mais comercializáveis se tornam esses produtos, menos excepcionais e especiais parecem, de modo que deixam de ser únicos e não-reproduzíveis. E, assim, quanto mais facilmente comercializáveis, menor sua capacidade de constituir a base para uma renda monopolista (2005, p.32-34). A dificuldade estaria, do ponto de vista do produto imobiliário, em encontrar o ponto ótimo entre a forma única (específica) e a forma genérica (universal).

O skyline que se constitui aparece, ele próprio, como uma marca - não por acaso algumas vertentes de planejamento urbano aproximam-se das estratégias empresariais de posicionamento de marcas, o branding. À primeira vista, a silhueta parece se repetir em lugares tão distantes e diferentes como Dubai, Pequim, Shangai, Medelin, Cidade do México, Johanesburgo e São Paulo.

Assim como nos edifícios isolados, é possível identificar, no conjunto que se constitui, certa homogeneidade na forma e no programa e, ao mesmo tempo, a busca por se projetar como espaço singular, mais atraente do que os demais. Novamente surge a contradição apontada: na tentativa de aumentar suas marcas de distinção, para alcan58 "A renda monopolista surge porque os atores sociais podem obter um fluxo de ganhos maior durante um período de tempo prolongado, em virtude de seu controle exclusivo sobre um determinado artigo, direta ou indiretamente, e que, em determinados aspectos cruciais, é único e não reproduzível” (Harvey, 2005, p.30). 
çar uma excepcionalidade que produza rendas monopolistas, essas paisagens tornam-se cada vez mais semelhantes.

A redução de barreiras comerciais, a desregulamentação financeira, o aumento da facilidade de transporte, entre outros aspectos da chamada globalização-ou mundializaçãofinanceira (Chesnais, 1998) -, significaram uma perda de poderes monopolistas, devido ao aumento da facilidade de deslocamento do capital entre as regióes. A luta por "capital simbólico coletivo" ${ }^{2}$ - pela acumulação de marcas de distinção - adquire importância maior como base de rendas monopolistas.

Essa busca motivou (ou justificou), em várias cidades, a adoção de modelos de planejamento urbano nos quais a competitividade urbana é ponto central. O chamado "planejamento estratégico de cidades", difundido no Brasil e na América Latina pela ação combinada de diferentes agências multilaterais e de consultores internacionais, virou uma espécie de receituário aplicado por toda parte (Arantes; Maricato; Vainer, 2000; Ferreira, 2007; Compans, 2005).

Não há, em São Paulo, contudo, um plano articulado de produção de espaços espetaculares que se apresente como uma política de promoção da cidade no mercado mundial, como no planejamento estratégico de cidades, proposto no Rio de Janeiro por consultores catalães, na década de 1990 (Arantes; Maricato; Vainer, 2000), ou no modelo Curitiba (Sanchez, 2003). Técnicos da administração pública, políticos e promotores imobiliários, no entanto, incorporaram uma série de elementos característicos dos novos modelos e os utilizam com frequência. $\mathrm{O}$ instrumento urbanístico de maior destaque é, como vimos, a Operação Urbana.

O fato de São Paulo figurar como "cidade global”, mesmo que de segunda linha, em rankings da literatura internacional, ${ }^{60}$ tem sido utilizado em discursos que procuram legitimar algumas propos-

${ }^{59}$ Harvey deriva o termo da obra de Bourdieu (2005, p.47-48). ${ }^{60} \mathrm{O}$ termo surgiu como hipótese analítica para compreender as mudanças pelas quais as cidades passaram, inicialmente formulada por John Friedman. A hipótese foi desenvolvida e modificada por Saskia Sassen, que preferiu o termo global para acentuar a especificidade do papel assumido pelas cidades na fase atual do sistema capita- tas ou obras na cidade. ${ }^{61}$ Operações urbanas, grandes projetos, revitalização do centro histórico e planejamento estratégico são algumas das novas expressões acionadas com grande frequência. $\mathrm{Na}$ prática, porém, vimos que, por trás do surgimento dos novos espaços, há um conjunto de agentes que procura interferir nos vetores de valorização do espaço urbano, de modo a melhor se inserir neles, ou tentando mudar-lhe o rumo. Uma espécie de jogo imobiliário da vida real (Zeckendorf, 1988), no qual a regra básica é intensificar o uso da terra, sempre que possível substituindo usos pouco rentáveis, como a habitação social, por empreendimentos lucrativos, como complexos luxuosos de todo tipo. Promotores imobiliários e seus parceiros institucionais, financeiros e do poder público fazem da cidade uma espécie de "máquina de crescimento" (Molotch; Logan, 1987).

Assim como outras cidades, São Paulo passou por uma redefinição que é parcial em duplo sentido: refere-se apenas a uma parte do que acontece na cidade e ocupa apenas uma parte do que se considera o espaço da cidade (Cf. Sassen, 1994). As transformações são restritas e confinadas ao que é estratégico: trechos da cidade que se destacam, enclaves ditos globais, cada vez mais desconectados do tecido da cidade, com técnicas mais sofisticadas de distanciamento e divisão social (Caldeira, 2001, p.255), que parecem não pertencer a seus arredores imediatos, mas a redes invisíveis (Cenzatti; Crawford, 1998, apud Caldeira, 2000, p.259).

lista. A tese ganhou força ao questionar o senso comum, à época, de que, com o desenvolvimento acelerado das trocas eletrônicas - por conta da crescente digitalização da atividade financeira e do fato de as finanças gerarem um produto desmaterializado e hipermóvel -, a localização não teria mais importância. Resumidamente, a globalização teria mudado a forma dominante de organização dos fluxos interfronteiras, levando ao enfraquecimento do Estado nacional como unidade espacial e à ascendência das cidades e regiões. Constitui-se uma nova geografia da centralidade, na qual algumas cidades são articuladoras-chave, em particular as global cities: Nova York, Londres e Tóquio. O termo ganhou destaque na universidade e certo alcance nos órgãos públicos e na mídia.

${ }^{61} \mathrm{O}$ uso se tornou mais frequente com a visita do urbanista Jordi Borja, um dos responsáveis pela propagação do modelo na América Latina, para seminário preparatório para outro, internacional, organizado pela Associação Viva o Centro, em 1994. Para uma reconstituição deste e de outros acontecimentos, ver Kara-José (2007, p.102-115). Cf. também Ferreira (2007). 
Essas paisagens parecem fazer parte de uma lógica geral que, de um lado, esbarra em obstáculos próprios de cada uma das formações nacionais e, de outro, vale-se de particularidades locais para se reproduzir. Entre os obstáculos, encontram-se o baixo padrão de acumulação de riqueza, que cria dificuldades para o financiamento dos megaprojetos, ou a debilidade da integração com os circuitos mundiais de acumulação, para citar alguns exemplos. E, entre as particularidades, há situações específicas, como a dos Emirados Árabes, onde a renda do petróleo é usada para negócios imobiliários em larguíssima escala, financiando megaprojetos, como um conjunto de ilhas artificiais que emula os cinco continentes, produzido também às custas da mobilização de uma gigantesca força de trabalho composta por migrantes sem direitos sociais (Davis, 2007). Também como a de Kabul, com o uso de expedientes ilegais de acesso à terra e utilização e recursos que, em princípio, deveriam ser aplicados na reconstrução da cidade, depois da devastação promovida pelo ataque norte-americano (Fontenot; Maiwandi, 2007); como Pequim, com a construção de espaços espetaculares e midiáticos para as olimpíadas que, segundo Anne-Marie Broudehoux (2004), serão futuramente destinados ao uso exclusivo da elite emergente; ou ainda como Buenos Aires, com a privatização de terras públicas, convertendo-se antiga área portuária em uma das áreas mais caras e exclusivas da cidade, com torres de escritórios e residências de alto padrão em Puerto Madero (Fix, 2002).

Essas paisagens se repetem na forma que Mike Davis batizou de evils paradises, ou paraísos do mal: antevisões do tipo de futuro ao qual estamos sendo conduzidos. A lógica espacial do neoliberalismo revive, de modo extremado, segundo Davis, antigos padrões de segregação, fantasmagorias como os arranha-céus de Dubai, construídos por uma multidão de trabalhadores migrantes, que, a qualquer momento, podem ser deportados e vivem em péssimas condições nos campos de trabalho. "Seus direitos desaparecem no aeroporto, onde agentes de recrutamento confiscam seus passaportes e vistos para controlá-los" (Davis, 2007, p.5), num sis- tema desregulado de compra de força de trabalho, não por acaso apontado como modelo a ser seguido por membros de uma missão do sindicato brasileiro da construção que visitou Dubai. ${ }^{62}$

Em síntese, são trechos de cidades que combinam elementos de um processo de homogeneização, ${ }^{63}$ que avançou especialmente na década de 1990, e aspectos específicos, mantidos quando os promotores imobiliários encontram potencialidades e limites próprios a cada formação social específica. Identificamos, neste texto, indícios de que a mundialização financeira marca as estratégias de alguns dos agentes privados que estão por trás da produção da paisagem urbana, ainda que não se configurem as mesmas interconexões entre o imobiliário e o financeiro que caracterizam outras economias. ${ }^{64}$

No caso do Brasil, a liberalização e a desregulamentação financeira inseriram novamente o país nos fluxos internacionais de capital, interrompidos com a crise da dívida e a derrocada do desenvolvimentismo, no contexto da crise da ordem de Bretton Woods (Carneiro, 2002). Contudo, ao contrário do ciclo desenvolvimentista, a liberalização foi responsável por atrair montantes elevados de capital financeiro especulativo, os mesmos que invadiram as periferias asiática e lati-

${ }^{62}$ www.sindusconbnu.org.br/noticias/noticia_n381.htm. Conferir também a resposta de um engenheïro que trabalhou em Dubai à pergunta "Como é a questão trabalhista?": "É bem diferente do que nós conhecemos no Brasil. Em primeiro lugar, não existe paternalismo, o que torna a relação empregador-empregado mais transparente e correta. É o empregado quem cuida do seu futuro, de seus seguros e, sobretudo, de manter seu emprego, por sua competência e interesse. O empregador garante o salário e as condições de trabalho, incluindo os instrumentos necessários. As leis são islâmicas, tendo o Alcorão como regra fundamental. A liberdade de relacionamento entre empregador e empregado é um dos fatores que contribui para o empreendedorismo que existe no país". (Carlos Leal, em entrevista reproduzida no artigo "Dubai e os megaprojetos", em Construção Mercado, n. $\left.{ }^{\circ} 60,11 / 7 / 2006\right)$. Davis lembra que a organização Human Rights Watch acusou os Emirados de construir sua prosperidade sobre "trabalho forçado", em 2003.

63 A homogeneização é associada “ao movimento universalizante do capital, arrebatando mesmo os espaços mais remotos a um único domínio. Apenas nesse sentido o capital é homogeneizador e abarcador" (Brandão, 2001).

${ }^{64}$ A financeirização, na hipótese apresentada por Braga (1997), "não decorre apenas da práxis de determinados segmentos ou setores - o capital bancário, os rentistas tradicionais - mas, ao contrário, tem marcado as estratégias de todos os agentes privados relevantes, condicionando a operação das finanças e dispêndios públicos, modificando a dinâmica macroeconômica”. 
no-americana (Tavares, 1999), em um quadro de aumento da mobilidade do capital e de busca por rentabilidade também fora dos países centrais. Entre os ditos "mercados emergentes", o Brasil foi o país que adotou mais tardiamente as políticas neoliberais de ajuste, recomendadas pelo FMI e pelo Banco Mundial, que se iniciaram com as medidas do governo Collor, no início da década de 1990. Por isso mesmo, as medidas de liberalização - comerciais, de flexibilização do mercado de trabalho, reformas econômicas e do Estado e privatizações foram executadas aqui de modo extremamente acelerado, em menos de cinco anos, pelo governo Fernando Henrique Cardoso (1999). Concluídas as reformas, o país tornou-se apto a participar do circuito da valorização financeira. Em um "mundo tão dominado por esses capitais fictícios e dominado, além disso, pela vertigem de valorizar o valor sem a mediação da produção, nada mais interessante do que transformar economias nacionais com alguma capacidade de produção de renda real, mas sem pretensões de soberania, em prestamistas servilmente dispostos a cumprir esse papel e, dessa forma, lastrear, ainda que parcialmente, a valorização desses capitais. Eliminados os maiores obstáculos a esse desempenho (a inflação, o descontrole dos gastos públicos, a falta de garantias dos contratos, a ilusão do desenvolvimentismo, dentre os principais deles), essas economias estão prontas a funcionar como plataformas de valorização financeira internacional” (Paulani; Pato, 2005).

As novas articulações e desarticulações com os circuitos globais, produzidas no contexto da liberalização financeira, parecem assumir, em "economias nacionais com alguma capacidade de produção de renda real" (não publicado), ou seja, que passaram por um processo de industrialização, a forma de uma espécie de "base hospedeira". Nesses países, que se encontram em uma situação intermediária na hierarquia do sistema mundial, a produção dessa base exige a concentração de investimentos públicos e privados capazes de, mesmo com um padrão de acumulação mais baixo, mimetizar os padrões encontrados nas cidades dos países centrais. A sua produção coloca em funcio- namento uma máquina imobiliária de crescimento que procura associar seus empreendimentos à imagem de uma cidade "globalizada", da "classe mundial", ou de "primeiro mundo". Cria-se uma nova paisagem de poder e dinheiro, que mobiliza setores do governo e frações do capital imobiliário, parceiros nas várias modalidades de apropriação do fundo público. ${ }^{65}$

O mito da cidade global corresponde, no plano da produção da cidade, ao esforço de "adequação" às supostas novas exigências e obrigações criadas pela globalização. "Adaptação", a palavra de ordem da globalização, como discute Chesnais (1996, p.25), e é também um termo-chave do receituário das cidades globais, tendo, na produção de novas centralidades, um ingrediente fundamental. O mito das cidades globais, no entanto, já nasce enfraquecido, e, por isso, ganha ares de farsa. Tem como miragem a reprodução, em escala modesta, do skyline que mimetiza os centros de comando e projeta, em um país semiperiférico, a imagem de uma cidade global.

Além da operação de transferência de riqueza que promove, a ponte era a extravagância que faltava para o efeito de conjunto que a nova centralidade produz. É mais uma marca de distinção na nova centralidade, ao mesmo tempo em que contribui para aproximá-la de outras miragens como essa no mundo. Impõe, com seu triunfo, contudo, uma celebração permanente que silencia aqueles que foram derrotados.

(Recebido para publicação em março de 2009) (Aceito em abril de 2009)

\section{REFERÊNCIAS}

ANDRADE, Júlia; ARANTES, Pedro; LEITE, José Guilherme; FIX, Mariana; WISNIK, Guilherme. Notas sobre a Sala São Paulo. Revista Pós, São Paulo, FAU/USP, 2001.

ARANTES, Otília. O lugar da arquitetura depois dos modernos. São Paulo: Edusp, 1993.

${ }^{65}$ São Paulo Cidade Global: fundamentos financeiros de uma miragem. Cf. também, a respeito, $O$ mito da cidadeglobal, de João Sette Whitaker Ferreira e "São Paulo Cidade Mundial?", de Stamatia Koliumba, entre outros. 
; MARICATO, Ermínia; VAINER, Carlos. Cidade do pensamento único: desmanchando consensos. Petrópolis: Vozes, 2000.

ARANTES, Paulo. A fratura brasileira no mundo. In FIORI, José Luis; MEDEIROS, Carlos (Org.) Polarização mundial e crescimento. Petrópolis: Vozes, 2001.

BONDUKI, Nabil. Origens da habitação social no Brasil. Arquitetura moderna, lei do inquilinato e difusão da casa própria. São Paulo: Estação Liberdade/Fapesp, 1998.

BORJA, Jordi; CASTELLS, Manuel. As cidades como atores políticos. Novos Estudos CEBRAP, São Paulo, n.45, p.152-66, jul. 1996.

Local y global: la gestión de las ciudades en la era de la información. Madrid: Taurus, 1997.

BOTELHO, Adriano. O urbano em fragmentos. A producão do espaço e da moradia pelas práticas do setor imobiliário. São Paulo: FAPESP, Annablume, 2007.

BRAGA, José Carlos de Souza. Financeirização global: o padrão sistêmico de riqueza do capitalismo contemporâneo. In: TAVARES, Maria da Conceição; FIORI, José Luís (Org.) Poder e dinheiro: economia política da globalização. Petrópolis: Vozes, 1997. p.195-242.

BRANDÃO, Carlos Antônio. A espacialidade da riqueza: notas teóricas sobre as principais determinações da dimensão espacial do desenvolvimento capitalista. Cadernos IPPUR, Rio de Janeiro, v.15, n.1, p.119-34, 2001.

CALDEIRA, Teresa. Cidade de muros: crime, segregação e cidadania em São Paulo. São Paulo: 34 Letras, 2000.

CARLOS, Ana Fani Alessandri. Espaço-tempo na metrópole. São Paulo: Contexto, 2001.

CARNEIRO, Ricardo. Desenvolvimento em crise. São Paulo: Unesp/IE-Unicamp, 2002.

CHESNAIS, François. Mundialização do capital. São Paulo: Xamã, 1996.

$$
\text { Xamã, } 1998 .
$$

(Org.). Mundialização financeira. São Paulo

CORDEIRO, Helena K. A 'cidade mundial' de São Paulo e o complexo corporativo do seu centro metropolitano. In SANTOS, Milton, et al. O novo mapa do mundo: fim de século e globalização. São Paulo, Hucitec/ANPUR, 1993 p.318-331.

D’ANDREA, Tiaraju Pablo. Nas tramas da segregação: o real panorama da polis. São Paulo, 2008. Dissertação (Mestrado em Sociologia) - Faculdade de Filosofia, Letra e Ciências Humanas, Universidade de São Paulo. 2008.

DAVIS, Mike. A renovação urbana e o espírito pós-moderno. Espaço \& Debates, São Paulo, NERU, n.27, p.92 97, 1989.

Planeta favela. São Paulo: Boitempo, 2006.

- MONK, Daniel Bertrand. (Org). Evil Paradises: dreamworlds of neoliberalism. [S.l.], New Press, 2007.

FELDMAN, Sarah. A configuração espacial da metrópole. In: CAMPOS, Candido; GAMA, Lúcia; SACCHETTA, Vladimir (Org.). São Paulo metrópole em trânsito. São Paulo: Editora Senac, 2004

FERNANDES, Edésio; AFONSIN, Betania (Coord.). A le e a ilegalidade na produção do espaço urbano. Belo Horizonte: Del Rey, 2003.

FERREIRA, João Sette Whitaker. O mito da cidade-global. Petrópolis: Vozes, 2007.

; FIX, Mariana. A urbanização e o falso milagre do Cepac. Folha de S. Paulo, São Paulo, 17 abr. 2001.

FERRO, Sérgio. Arquitetura e trabalho livre. (Apresenta- ção: Pedro Fiori Arantes. Posfácio: Roberto Schwarz). São Paulo: Cosac Naify, 2006.

FIORI, José Luis; TAVARES, Maria da Conceição (Orgs.) Poder e Dinheiro. Uma economia política da globalização. Petrópolis: Vozes, 1997.

FIX, Mariana. Parceiros da exclusão: duas histórias da construção de uma "nova cidade" em São Paulo: Faria Lima e Agua Espraiada. São Paulo: Boitempo, 2001.

. O PT diante do BID. Correio da Cidadania, São Paulo, Ed.314, Semana 21 a 28 setembro 2002.

São Paulo S/A: acesso pelos fundos. Retrato do BrasillReportagem: Oficina de Informações, São Paulo, n.58, p.49, jul. 2004 .

A ‘fórmula mágica’ da parceria público-privada: operações urbanas em São Paulo. In: SCHICCHI; BENFAT (Org.). Urbanismo: dossiê São Paulo - Rio de Janeiro. Campinas: PUCCAMP/PROURB, 2004. p.185-198.

São Paulo: cidade global: fundamentos financeiros de uma miragem. São Paulo: Boitempo, 2007.

; TANAKA, G.; ARANTES, P. F. City report, slums and poverty: São Paulo. Report. London: DPU/UN-Habitat, 2003. Disponível em: www.ucl.ac.uk/dpu-projects/Global Report/cities/saopaulo.htm

FONTENOT, Anthony; MAIWANDI, Ajmal. Capital of chaos: the new Kabul of wardlords and infidels. In: DAVIS, Mike; MONK, Daniel Bertrand (Org). Evil Paradises: dreamworlds of neoliberalism.[S.l.] New Press, 2007. p.69-86.

FRUGOLI, Heitor. Centralidade em São Paulo: trajetórias, conflitos e negociações na metrópole. São Paulo: Cortez/ Edusp/Fapesp, 2000.

FUJIMOTO, Nelson. A produção monopolista do espaço urbano e a desconcentração do terciário na gestão da cidade de São Paulo: o caso da avenida Engenheiro Luís Carlos Berrini. São Paulo, 1994. Dissertação (Mestrado em Geografia) - Faculdade de Filosofia, Letras e Ciências Humanas, Universidade de São Paulo. 1994.

HALL, Peter. Cidades do amanhã. São Paulo: Ed. Perspectiva, 1995.

HARVEY, D. The urban experience. Baltimore: The Johns Hopking University Press, 1989.

. Do gerenciamento ao empresariamento: a transformação da administração urbana no capitalismo tardio. Espaço \& Debates, São Paulo, n.39, p.48-64, 1996.

Limits to capital. Londres: Verso, 1999.

El arte de la renta: la globalización y la mercantilización de la cultura. In: Capital financiero, propriedad inmobiliaria y cultura. Barcelona: Universidad Autónoma de Barcelona, 2005.

. Novo imperialismo. São Paulo: Edições Loyola, 2004.

Land rent under capitalism. In: . The urbanization of capital. Baltimore: The Johns Hopkins University Press, 1985.

JAMESON, Fredric. Pós-modernismo: a lógica cultural do capitalismo tardio. São Paulo: Ática, 1996

KARA-JOSÉ, Beatriz. Políticas culturais e negócios urbanos. São Paulo: Fapesp, Annablume, 2007.

LEFEVRE, Rodrigo. Novas sobre o papel dos preços de terrenos em negócios imobiliários de apartamentos de escritórios, na cidade de São Paulo. In: MARICATO, Ermínia (Org.). A produção capitalista da casa (e da cidade) no Brasil. São Paulo: Alfa-Omega, 1979.

LIMA, João da Rocha; ALENCAR, Cláudio Tavares de. Os atributos do mercado brasileiro de Empreendimentos de Base Imobiliária para Captar Recursos de Investidores 
Estrangeiros. In: SEMINÁRIO INTERNACIONAL DO LARES, 6, 16-17 nov., 2006. Anais... São Paulo: Latin American Real Estate Society, 2006.

MARCUSE, Peter; KEMPEN, Ronald Van. Conclusion: a changed special order. In: Globalizing cites: a new spatial order? Oxford: Blackwell Publishers, 2000. p.249-275. MARICATO, E. Metrópole na periferia do capitalismo: ilegalidade, desigualdade, violência. São Paulo: Hucitec, 1996

. A produção capitalista da casa (e da cidade) no Brasil. São Paulo: Alfa-Omega, 1979.

MARQUES, Eduardo; SARAIVA, Camila. A dinâmica social das favelas da região metropolitana de São Paulo. In: : TORRES, Haroldo. São Paulo: segregação, pobreza e desigualdades sociais. São Paulo: Editora SENAC-SP, 2004

; TORRES, Haroldo. São Paulo no contexto do sistema mundial de cidades. Novos Estudos CEBRAP, São Paulo, n.56, mar. 2000.

MARQUES, Rosa. Teias da desinformação. Retrato do Brasil/Reportagem, São Paulo, n.46, p.43-44, jul. 2003.

MASSONETO, Luis Fernando. Operações urbanas consorciadas: a nova regulação urbana em questão, 2003. Procuradoria-Geral do Município, Porto Alegre, Prefeitura Municipal de Porto Alegre, n.17, p.101-118, 2003.

MODERNO e luxuoso, o Plaza Iguatemi abrigará, a partir de julho, alguns dos escritórios mais importantes de São Paulo. Revista Vejinha São Paulo, v.35, n.25, p.10-16 jun. 2002.

MOLOTCH, H. L.; LOGAN, J. R. Urban fortunes. BerkeleyCA: University of California Press, 1987.

NOBRE, Eduardo Alberto Cube. Reestruturação econômica e território: expansão recente do terciário na marginal do rio Pinheiros. São Paulo, 2000. Tese (Doutorado em Estruturas Ambientais Urbanas) - Faculdade de Arquitetura e Urbanismo, Universidade de São Paulo. 2000

OLIVEIRA, Francisco de. Privatizacão do público, destituiç̃a da fala e anulação da política: o totalitarismo neoliberal. In: ___ PASOLI, Maria Célia (Org.) Os sentidos da democracia: política do dissenso e a hegemonia global. Petrópolis: Vozes, 1999.

O atraso da vanguarda e a vanguarda do atraso. In: PAOLI, M. C.; OLIVEIRA, F. de. Os sentidos da democracia. Petrópolis: Vozes, 1999.

. Estado, mercado, incerteza: matrizes da corrupção anti-republicana. Proposta, Rio de Janeiro, n.91, p.95105, fev./dez. 2001.

O ornitorrinco. In: Crítica à razão dualista/ O ornitorrinco. São Paulo: Boitempo, 2003.

OTTONI, Dacio. Introdução. Cidade Jardim: formação e percurso de uma idéia. In: HOWARD, Ebenezer. Cidadesjardins de amanhã. São Paulo: Hucitec, 1996. p.10-101.

PAULANI, Leda Maria; PATO, Christy. Investimento e servidão financeira: o Brasil do último quarto de século. In: PAULA, João Antonio (Org.). Adeus ao desenvolvimento: a opção do governo Lula. Belo Horizonte: Editora Autêntica, 2005.
TASCHNER, Suzana Pasternak. Favelas e cortiços no Brasil: 20 anos de pesquisas e políticas. Cadernos do LAP São Paulo, FAU/USP, n.18, 1997.

TAFURI, Manfredo. The disenchanted mountain: the skyscraper. In: CIUCCI, Giorgio; DAL CO, Francesco; MANIERI-TAFURI, Manfredo. The american city: from the civil war. Cambridge-Mass: The MIT Press, 1979. p.398-503.

ROLNIK, Raquel. A cidade e a lei: legislação, política urbana e territórios na cidade de São Paulo. São Paulo: Studio Nobel, 1997.

SAES, Flávio. São Paulo republicana: vida econômica. In: PORTA, Paula (Org.) História da cidade de São Paulo: a cidade na primeira metade do século XX. São Paulo: Paz e Terra, 2004. v.3

SAMPAIO JÚNIOR, Plínio de Arruda. O impasse da formação nacional. In: FIORI, José Luis. (Org.) Estados e moedas no desenvolvimento das nações. Petrópolis: Vozes, 1999. p.415-448.

SANCHEZ, Fernanda. A reinvenção das cidades para um mercado mundial. Chapecó-SC: Argos, 2003.

SANTOS, Laymert Garcia dos. São Paulo não é mais uma cidade. In: PALLAMIN, Vera (Org.) Cidade e cultura. São Paulo: Estação da Liberdade, 2002.

SÃO PAULO. Prefeitura da Cidade de. Prospecto de Registro (o "Prospecto") da Operação Urbana Consorciada Faria Lima, 26 de outubro de 2004.

SASSEN, Saskia. Locating cities on global circuits. In: Cities in a world economy. London: Pine Forge, 1994. p.1-36.

SAULE JÚNIOR, Nelson; CARDOSO, Patrícia. Direito à Moradia no Brasil: violações, práticas positivas e recomendações ao governo brasileiro. São Paulo: Instituto Pólis, 2005. (Relatorias Nacional e Especial da ONU, durante duas semanas, nos meses de maio e junho de 2004).

SEABRA, Odette Os meandros dos rios nos meandros do poder. Tietê e Pinheiros: valorização dos rios e das várzeas na cidade de São Paulo. 1987. Tese (Doutorado) Faculdade de Filosofia, Letras e Ciências Humanas da Universidade de São Paulo. 1987.

SHIFFER, Sueli (Org.). Globalização e estrutura urbana. São Paulo: Ed. Hucitec, 2004.

VILLAÇA, Flávio. Espaço intra-urbano no Brasil. São Paulo: Studio Nobel/Fapesp, 1998.

Elites, desigualdade e poder municipal. In: CAMPOS, Candido; GAMA, Lúcia; SACCHETTA, Vladimir (Org.) São Paulo Metrópole em trânsito. São Paulo: Editora Senac, 2004

WISNIK, Guilherme. Estado crítico: à deriva nas cidades. São Paulo: Publifolha, 2009 .

ZECKENDORF, William; McFREARY, Edward. Zeckendorf: an autobiography of William Zeckendorf. Chicago: Plaza Press, 1988.

ZUKIN, Sharon. Landscape of power. Berkeley-CA: University of California Press, 1993. 


\section{A BRIDGE TO SPECULATION - the art of rent in the staging of a "global city"}

\section{Mariana Fix}

This paper analyzes the conflicts and articulations behind the transformation of an old swampish area, the meadows of the Pinheiros river, in one of the most valued regions of São Paulo and its globalized face. The text discusses particularly the connections made in the last decades between the global financialization of the economy and the specific arrangements that take place in São Paulo; among supposedly advanced mechanisms - such as urban operations, Cepacs and real estate investment funds and typical forms of primitive accumulation, in which strength, frauds, oppression and pillage are recurrently exhibited; between the "city proper" of the elites and the so-called clandestine city, that occupies stream edges, hillsides, margins of dams. I investigate three icons of that urban landscape: a cable-supported bridge, synthesis of the "new city" scenery; a gigantic walled development, that mixes residential, luxury trade and office buildings; and a business compound with office and hotel towers, interlinked by an underground shopping center.

KEYwORDS: globalization, financialization, real state, São Paulo, global city.

\section{UN PONT À LA SPÉCULATION - l'art de la rente dans la montage d'une "ville globale"}

\author{
Mariana Fix
}

Cet article analyse les conflits et les négociations sous-jacentes à la transformation d'une ancienne région inondée, la plaine inondable du fleuve Pinheiros, située dans l'une des parties les plus valorisées de São Paulo et maintenant son côté mondialisé. On y présente en particulier les liens établis au cours des dernières décennies entre la financiarisation mondiale de l'économie et les agencements spécifiques qui surgissent à São Paulo; entre des mécanismes supposés avancés - tels les plans d'actions urbains, les Cepacs et les fonds d'investissement immobilier - et des formes typiques d'accumulation primitive dans lesquelles la force, la fraude l'oppression et le pillage se répètent constamment; entre la "ville typique" des élites et la ville, dite clandestine, qui occupe les bords des ruisseaux, les pentes des collines, les bas-côtés des barrages. Trois icônes de ce paysage urbain nous servent de points de repère:un pont suspendu, uneimage synthèse de la scénographie de la "nouvelle ville"; une œuvre gigantesque murée qui mélange des résidences, des commerces de luxe et des bureaux; et un complexe d'entreprises avec des tours de bureaux et d'hôtels liées entre elles par un centre commercial souterrain.

MotS-CLÉs: mondialisation du capital, financiarisation, propriété foncière, São Paulo, ville globale.

Mariana Fix - Arquiteta e urbanista formada na Faculdade de Arquitetura e Urbanismo da Universidade de São Paulo. Doutoranda no Instituto de Economia da Unicamp. Mestre em sociologia no Departamento de Sociologia da Faculdade de Filosofia Ciências e Letras da USP. Professora do curso de Design das Faculdades Campinas (Facamp) e integrante do Laboratório de Habitação e Urbanismo da FAUUSP. Suas mais recentes publicações são: Parceiros da exclusão. Duas histórias da construção de uma "nova cidade" em São Paulo: Faria Lima e Água Espraiada (Boitempo 2001); São Paulo cidade global: fundamentos financeiros de uma miragem (Boitempo 2007). 